\title{
CLAUDIA APPOLLONI
}

ORCID: 0000-0002-5138-4919

\section{A PRAGMATIC THEORY OF EVERYDAY IMPOSITION OF WORDS IN AN ANONYMOUS THIRTEENTH-CENTURY COMMENTARY ON DE ANIMA (MS PRAGUE, METROPOLITAN CHAPTER, M. 80, FF. 54VA-55RB) ${ }^{* *}$}

Keywords: Anonymous of Prague, Commentaries on De anima, Medieval Pragmatics, Medieval Semantics, Roger Bacon

* Claudia Appolloni-PhD candidate at the Fondazione San Carlo of Modena and the University of Geneva. She works on medieval philosophy and linguistics, focusing on $13^{\text {th }}$-century pragmatic theories of signification. Since September 2020 she is a research fellow at the University of Bologna, where she works on the philosophical manuscripts of the Franciscan library of Santa Croce (Florence).

Address for correspondence: Alma Mater Studiorum - Università di Bologna, Dipartimento di Filosofia e Comunicazione, Via Azzo Gardino 23, Bologna, Italy. E-mail: claudia.appolloni@unibo.it.

** I am extremely grateful to Laurent Cesalli and Costantino Marmo for the discussions that helped me to develop this paper; and to Frédéric Goubier, Irène Rosier-Catach and Luisa Valente for allowing me to improve it with their insightful advice and discussions. I would also like to thank Jennifer Ottman, Monika Mansfeld, and Rega Wood for providing me with their working material and transcriptions. Furthermore, my gratitude goes to all conference participants, to the editors of the volume, and to peer reviewers for their comments, corrections, and excellent advice. All errors and shortcomings are, of course, my sole responsibility. 


\section{Introduction}

In a broad sense, contemporary pragmatics is defined as "the study of language use in context" and, within the analytic philosophy of language, as "the systematic study of meaning by virtue of, or dependent on, the use of language." Pragmatic approaches to signification are also found in the history of medieval logic and semantics, and such a study can count on at least forty years of research. ${ }^{2}$ After all these years, Roger Bacon (1214/1220-92) continues to attract great interest in this field as well as in the reconstruction of the pragmatic approaches to language in the Middle Ages, which are focused on the relationship between signs and their users. ${ }^{3}$ In fact, his theory of the everyday imposition of words is highly original and almost unique in the semantic panorama of the thirteenth century. ${ }^{4}$

According to Bacon, the imposition of words (the act of giving meaning according to medieval thinkers) does not produce the meaning as an invariant property of words, but speakers can — at least in theory-operate a continuous and tacit renewal of the meanings of words, a process that scholars called the "reimposition of words." This process characterizes language in its ordinary, everyday practice and reveals its intrinsic dynamism. Like Bacon, another Franciscan, Peter John Olivi (ca. 1248-98) shares a similar concept of signification that was also labeled "pragmatic," since the words signify not by an intrinsic acquired property but rather by an act of bestowing meaning that involves the speakers qua users of language and depends on their intention to signify. ${ }^{5}$ Hence, for both Bacon and Olivi,

1 Huang, 2017, p. 1.

2 I will mention the most important studies below: see, especially, $\S 2$ and its footnotes.

3 See Marmo, Rosier-Catach, 2011, p. 1.

${ }^{4}$ As we shall see, Anonymous of Prague supports a similar theory of the everyday imposition of words, see $\S 2$.

5 I base this reconstruction on Cesalli, Majolino, 2014, who identified at least two opposing approaches in 13th-century theories of the signification of names, which they called the poiesis-oriented or artefactual approach (i) and the praxis-oriented or pragmatic approach (ii). According to (i), the meaning of words is the result of an initial act of imposition, after which words have the intrinsic property of "meaning something." In contrast, according to (ii), meaning is an act performed by the speakers - i.e., language users - who intentionally aim to signify something. On the one hand, the model is the production of an artifact; on the other hand, it is the use of an instrument: see Cesalli, Majolino, 2014, $\S \S 125-200$. For a further bibliography on this, see Appolloni, 2020. 
the meanings of words depend on the activity of signifying performed by the speakers-users of a language. Acknowledging the crucial role of the intentions of users, scholars agree on the strong influence of Augustinian linguistics on the two theologians and, more generally, on thirteenth-century pragmatic accounts of the signification of names. ${ }^{6}$ While Aristotle's logica nova and natural philosophy, commented on at mid-thirteenth century faculties of arts, serves as the basis for theories more concerned with the formal aspects of language such as early Modism, theologians are more influenced by Augustinian semiotics and semantics, which insist on the intersubjective and pragmatic aspects of sign and language. ${ }^{7}$ This Augustinian influence is one of the forms that interactions between theological sources and the liberal arts - and the intersections between them - took in the thirteenth century. ${ }^{8}$

In this paper, I attempt to add a piece to the puzzle of reconstructing thirteenth-century pragmatic theories of imposition and signification of names. In particular, I examine a theory of the everyday imposition of words advocated by an anonymous, (probably) thirteenth-century master of the arts. His question-commentary on Aristotle's De anima, from which I edit three questions below, is preserved in a single manuscript, M. 80, in the Metropolitan Library of Prague (ff. 42rA-89rA). ${ }^{9}$ Although his theory of everyday imposition sounds similar to that of Bacon, Anonymous of Prague ${ }^{10}$ emphasizes the need, in the act of everyday imposition, to obtain the consent (consensus) of others and the linguistic community rather than individual semantic freedom.

6 See Mora-Márquez, 2011, pp. 163-164; Mora-Márquez, 2015, pp. 61-70; Rosier-Catach, 1994, pp. 123-155. For the Augustinian linguistics, see Vecchio, 1994.

7 On the opposition between Augustine and Aristotle as "two models of occidental medieval semantics," the former more concerned with pragmatic aspects and the latter with language as a formal system, see Rosier-Catach, 2000. This picture does not exclude that there were masters in the arts, for example, the grammarians known as "intentionalists," who advocated a pragmatic approach to language; as Rosier-Catach argues, Augustine was part of their background, Rosier-Catach, 2000, p. 46.

${ }^{8}$ On such intersections, see Marmo, 2010; Rosier, 1994; Rosier-Catach, 2004.

9 Praha, Archív Pražského hradu, fond Rukopisy, Knihovny Metropolitní kapituly u sv. Víta M. 80.

${ }^{10}$ It may be important to note that by "Anonymous of Prague" I am not referring to the Anonymous Pragensis of manuscript Praha, Knihovny Metropolitní Kapituly, L66, 81rA-91vA, who belonged to a modist milieu [see Anonymus Pragensis, Quaestiones super Aristotelis Sophisticos Elenchos (ed. Murè, 1998) and Marmo, 1994, p. 497]. 
To examine the content of the three questions edited and to contextualize them I: i) analyze some thirteenth-century commentaries on De anima II. 8 as the doctrinal context in which we can read the text; ii) examine the details of Anonymous of Prague's doctrinal position and how it differs from Bacon's theory of meaning; and iii) highlight some elements that exclude Bacon as being the author of the edited questions.

\section{Thirteenth-Century Commentaries on De anima II.8}

Translated for the first time by James of Venice in the twelfth century, Aristotle's De anima was widely commented on at faculties of arts from the midthirteenth century, when the prohibition on reading it was lifted and courses on De anima became mandatory. ${ }^{11}$ These circumstances offered medieval thinkers the opportunity to broaden their reflection on various philosophical issues. Taking their cue from De anima II.8, 420b5-421a6, Aristotle's medieval commentators examine the utterance and what makes it meaningful, an aspect that may seem secondary but which yields results of particular interest for theories of language.

Aristotle defines the vocal sound, ${ }^{12}$ or voice (vox, in medieval translations of the Greek $\varphi \omega v \grave{\eta})$, in the context of an examination of the five senses, in particular, hearing, showing its difference from sounds produced by striking the air in the vocal tract (or trachea), such as a cough. ${ }^{13}$ Different from a cough, a vocal sound is not only produced by "an animated being" but also "with some sort of image" or "imagination" (aliqua imaginatio); therefore, a vocal sound is significant, whereas a cough is not. Hence, the vocal sound is a significant sound produced by animals having imagination. Not all animals, however, can utter vocal sounds: it is necessary to have vocal cords, which is why (for example) fish lack a voice.

11 See Gauthier, 1984, p. 236.

12 "Utterance" is the standard translation for vox; however, I prefer "vocal sound" because it is more literal.

13 See Aristoteles Latinus, Iacobus Veneticus translator Aristotelis. De anima II. 8 (ed. Decorte, Brams, ALD; 420b5-420b34); Aristoteles Latinus, Guillelmus de Moerbeka revisor translationis Aristotelis secundum Aquinatis librum. De anima II.8 (ed. Gauthier, 1984, p. 143; 420b5-420b34). 
Dealing with the Aristotelian passage, medieval thinkers were confronted with various questions about language yielded by the interpretation of the excerpt produced. What I present in this section are only some of them, ${ }^{14}$ since I intend to provide only a conceptual framework for the questions edited below. ${ }^{15}$ First of all, how should the definition of vocal sound as a significant sound (sonus significativus) with a certain image (cum aliqua imaginatione $)^{16}$ be understood?

One of the earliest elaborations of this problem is found in Albert the Great's De homine, part of the Summa de creaturis, dated around the early 1240s. ${ }^{17}$ Although Albert the Great refers to the entire work as De homine, when he deals with specific questions he also calls it Quaestiones De anima/ Quaestiones in tractatu De anima, or rarely Tractatus De anima.$^{18}$ In this work, in a section entitled De voce, ${ }^{19}$ Albert deals with two questions that are particularly relevant for theories of language: 1 ) whether the vocal sound always signifies a mental image or a natural affection (Utrum vox sit semper signum imaginationis vel affectus naturae); and 2) how words (dictiones) signify concepts.

Albert's De homine builds on Avicenna's Liber de anima in considering imagination as the lowest faculty of the inner sense, common to humans and animals. Its function is to preserve the images received by the external senses as forms without matter, and it prepares them for further elaboration by the higher faculties..$^{20}$ Animals with a trachea, says Albert, produce a vocal sound (vocant), and this vocal sound is a sign of imagination and natural affection. Affections drive animals to produce a voice to express and realize their desires (food, protection, etc.). However, for human language to be

14 I leave aside, for example, the question about the innateness of language, for which see Ebbesen, 2017a, 2017b, 2020; Sekizawa, 2010.

15 For a detailed reconstruction of this context, see Köhler, 2014.

16 Although in the translations aliqua imaginatione leads us to think of it as a certain mental image, there remains an oscillation among medieval authors in considering "imagination" as a certain mental image or as the faculty of imagination. On this point, see Magee, 1989, p. 100; Rosier-Catach, 1994, p. 304; Valente, forthcoming.

17 Anzulewicz, Söder, 2008, p. XV.

18 Anzulewicz, Söder, 2008, pp. VII-XIII.

19 For the French translation and the discussion of this passage, see Rosier, 1994, pp. 303-315.

${ }^{20}$ Marmo, 2020, p. 86 and bibliography cited. 
contained within the definition of vox as signum imaginationis (1), Albert argues that the vocal sound can be either definite or confused, depending on whether imagination dominates instinct, as in humans, or is dominated by it, as in animals. ${ }^{21}$ In fact, influenced also here by Avicenna's Liber de anima, Albert states that the signs produced by animals are confused because they are natural: since nature is the same in all, all animals' vocal sounds are similar, and the similarity is the cause of non-distinction. On the contrary, for humans, signs are definite and differentiated because they are established by an institution and at pleasure (a placito). ${ }^{22}$ In Peri Hermeneias (ca. 1250), Albert leaves aside the definite/confused distinction and points out that the vox can signify an image as animal affection (imago affectiva) or an image as abstracted in a concept (conceptum), as in human rational language. ${ }^{23}$ This

${ }^{21}$ Albert the Great, De homine II (ed. Anzulewicz, Söder, 2008, pp. 214-215): "Dicimus quod multa animalia vocant et non solus homo. Quaecumque enim per pulmonem attrahunt aërem et habent arteriam vocativam et imaginationem, vocant et non alia. Et dicimus quod vox eorum significat imaginationem. Sed signum est duplex, scilicet formatum et informe, sive distinctum et confusum. Distinctum autem vocis signum non est a natura, sed a placito et institutione; et hoc non est nisi in illis animalibus, in quibus imaginatio dominatur super instinctum naturae, ita quod potest abstinere ab ipso et imitari eum, sicut est in homine. In aliis autem animalibus, in quibus imaginatio causatur ab instinctu naturae et sequitur eum per omnia - cuius signum est, quia non faciunt consilia nec inquisitiones suorum operum-, in illis etiam signum imaginationis non est nisi per naturam et non ab institutione. Et quia natura est eadem in omnibus, propter hoc suae voces et sua opera sunt similia in omnibus. Et quia similitudo causa est indistinctionis, propter hoc suae voces manserunt indistinctae nec unum animal percipit ex voce alterius nisi desiderium eius in commune, scilicet indigentiam cibi et desiderium coitus et nocumentum laesionis et vocationem societatis. Et in his desideriis etiam aliquo modo variant voces suas."

${ }^{22}$ Rosier-Catach found that Avicenna's Liber de anima was behind this distinction, where the Arab philosopher claims that animals communicate (significant) their desires in a natural and confusing way (naturaliter et confuse), while humans have different and ad placitum signs with which they can express the infinity of their desires. See Rosier, 1994, p. 208, n. 23. See Avicenna Latinus, Liber de anima seu Sextus de Naturalibus. $I V-V$ (ed. Van Riet, 1968, pp. 72-73). See also Rosier-Catach, 2006, pp. 454-458; Rosier-Catach, 2015, p. 232. However, it seems to me that, while inspired by Avicenna, Albert goes slightly further in explaining that distinction in the way we have seen (linking expressly, for example, animal language, and not only animal knowledge, to instinct).

${ }^{23}$ Albert the Great, Peri hermeneias, lib. I, tract. 2, cap. 1 (ed. Borgnet, 1890, p. 382): "Quamvis ergo vox sit sonus, tamen (quia sonus non est nisi fractio et ictus aeris a percutiente solido plano percussus, tympanum auris immutans) non omnis sonus est vox: 
makes it possible to explain the Aristotelian definition of vox as a significant sound with a certain image, even if the meaning is a concept or species intelligibilis expressed by humans.

Like Albert, other medieval commentators on the De anima investigate the definition of vox and the role of imagination in its formation. In the earliest commentaries, the interest in linguistic issues is not well developed, especially in exposition-commentaries. ${ }^{24}$ Question-commentaries, adopted around 1250 by arts masters as a dialectical approach to teaching, become more sophisticated..$^{25}$ This is the case with two English commentaries from the 1260s: ${ }^{26}$ on the subject concerned, both Anonymous' Quaestiones in tres libros De anima, edited by Vennebusch (1963), and Geoffrey of Aspall's Quaestiones super De anima show their dependence on Albert the Great's De voce (rather than on his later De anima ca. 1254-1257). Anonymous of Vennebusch approves the Aristotelian definition of vox and clarifies Albert's conception by distinguishing between definite and confused vocal sounds according to the different nature of the representations involved. The definite vocal sound is specific to humans since they have definite and distinct affections; and the confused one is specific to animals

quia vox est sonus ab ore animalis, cum imagine alicujus significationis prolatus. Haec enim imago potest esse affectiva et movens ad immutationem vel fugam: et tunc vox significat passionem gaudii, vel doloris, vel tristitiae, sicut plerumque significant voces brutorum, et etiam rationalium quorumdam, ut gemitus et ea quae importantur per interjectiones. Imaginatio potest etiam esse a re accepta in qua accipit ratio veritatem vel falsitatem, vel cujuslibet rei verum conceptum: et hoc modo sonus cum imaginatione sermonis prolatus non est nisi hominis, etiam illa sola vox vere erit vox." On this, see Rosier, 1994, p. 308.

${ }^{24}$ See Richard Rufus of Cornwall, Sententia cum quaestionibus in libros De anima Aristotelis (ed. Ottman, Wood, Lewis, Martin, 2018, pp. 378-381); Adam Buckfeld, In Aristotelis De anima (Bologna, Biblioteca universitaria 2344, f. 39v; I thank Jennifer Ottman, who provided me with her working transcription of the text); Anonymous Bodley, Sententia super II et III de anima (ed. Bazan, 1998, p. 218); Anonymous Rome, Lectura in librum de anima (ed. Gauthier, 1985, p. 352). For the structure of thirteenth-century De anima commentaries, see Bazan, 2002 and, more generally, Weijers, 2002.

25 Bazan, 2002, p. 143.

${ }^{26}$ However, for Anonymous of Vennebusch, the Oxford origin is only hypothetical: see Bazan, 2002, p. 150. 
since they express confused affections. ${ }^{27}$ Following Albert's De voce, Geoffrey of Aspall wonders how animals of the same species, although they have a confused voice, can understand one another's determined desire for a given thing. He argues that there is a certain degree of diversification between voices based on the expression of four common needs (i.e., food, help, sex, and care), which are the only things they can understand. ${ }^{28}$ Yet, Anonymous of Siena, an arts master from the same period and milieu, puts into question the universal validity of Aristotle's definition of vox as meaning a certain image (because it might exclude the intelligible) ${ }^{29}$ This definition seems consistent when we speak about an animal's vocal utterance, which is natural (vox naturalis), that is when the imagination moves the virtus appetitiva to utter a vox. ${ }^{30}$ On the other hand, human beings can establish the meaning of words by means of the intellect, a faculty that is superior to the imagination. This allows human beings to signify the intelligible, thanks to an act of reason (ex actu rationis), and to signify it by institution or ad placitum $;{ }^{31}$ thus, only the human vox is properly meaningful. ${ }^{32}$

27 Anonymous of Vennebusch, Quaestiones in tres libros de anima (ed. Vennebusch, 1963, pp. 220-221): "Unde bruta non habent ymaginaciones ad significandum nisi secundum affectus generales confusos [...] et secundum istas diversas ymaginaciones, de quibus habent desiderium significandi in universali et confuse, habent similiter voces distinctas generales et confusas."

${ }^{28}$ Geoffrey of Aspall, Quaestiones super De anima (ed. Čizmić, 2005, p. 321): “Dico quod in brutis et avibus ita est, quod unum comprehendit desiderium alterius in communi tantum. Ista autem communia numerantur per quatuor. Quorum unum est indigentia cibi, secundum est invocacio sociorum, tertium desiderium choitus, quartum nocumentum lesionis. Et in hiis quatuor possunt bruta comprehendere desiderium individuorum sue speciei. Unde in hiis quatuor habent voces aliquantulum diversificatas, per quarum diversitatem potest unum brutum comprehendere desiderium alterius quoad unam rem determinatam."

29 Anonymous of Siena, Quaestiones super librum de anima, q. 83d (ed. Bernardini, 2009, p. 251).

30 Anonymous of Siena, Quaestiones super librum de anima, q. 83d (ed. Bernardini, 2009, p. 257).

31 Anonymous of Siena, Quaestiones super librum de anima, q. 83d (ed. Bernardini, 2009, p. 256).

32 Anonymous of Siena, Quaestiones super librum de anima, q. 83d (ed. Bernardini, 2009, p. 256): “Ad quartum quesitum dicendum quod omnis vox est significativa, vel sui ipsius, ut buba, vel alicuius rei alterius prius ymaginate vel concepte quam intendit ymaginans exprimere. Set alia est vox instituta ad significandum ex actu rationis, et talis 
After the discussion of question (1), in De voce, Albert the Great deals with the second issue (2) - already discussed by Irène Rosier-Catach ${ }^{33}$ concerning vocal sounds that signify concepts (intellectus et species intellectus), namely, words (dictiones significative). Here, the issue deals with the interaction between the phonic matter of vox and the species intelligibilis, and the question concerns the way an immaterial species is attached to the phonic matter. As Rosier-Catach points out, the question is about how meaning is linked to the utterance during the first institution and how this meaning can be transmitted in every uttering; in other words, it is all about the relationship between the first imposition and the actual use of the signs. ${ }^{34}$ According to Albert, humans have a potentia interpretativa, which is our ability to engender species into the vocal sounds, so that the generation of signification follows the virtual impression of a species on phonic material by such a potentia interpretativa. ${ }^{35}$ However, in the act of uttering, it is only a copy of the species we have in mind that comes into the vocal sound since the original one remains inside our soul. This generation of words does not depend on the will alone: if it did, we could decide to signify whatever we want and however we want, for example, "donkey" with the word homo. ${ }^{36}$ Our potestas can impress meanings on vocal sounds but it does so according to the meanings established by the first impositor, which potentially remains

instituta est ad placitum: et talis vox solum fit ab anima racionali, et est proprie significativa, et sic verum est quod quedam est significativa et quedam non, set primo modo omnis vox est significativa. [...] Vel dicendum quod uno modo accipitur ymaginabile ab ymaginativa virtute et ipsa virtus ymaginativa movet virtutem appetitivam, et ipsa mota movet organa ad proferendum vocem, set hec vox est naturalis. Et sic concedendum quod omnis vox est ipsius ymaginative. Alio modo imponitur vox a virtute superiori virtute ymaginativa ut ab intellectu, et tunc non est vox naturalis, set ad placitum, et possunt sic significari res intelligibiles ut substancie spirituales et alie." This idea seems to be closer to Albert's De anima, even if it is not clear who was influenced by the other (see Bernardini, 2009, pp. LXX- LXXXIII).

33 Rosier, 1994, pp. 309-315.

34 Rosier, 1994, p. 123. Commenting on Roger Bacon's De signis, Cesalli, de Libera, Goubier, and Rosier-Catach claim that the speaker's use could consist of a "validation", that is, the use of the sign according to the meaning originally imposed, or of a renovation of meaning, namely, a new imposition or deviation from the imposed meaning. See Cesalli, de Libera, Goubier, Rosier-Catach, forthcoming, § 147.

35 Albert the Great, De homine lib. II (ed. Anzulewicz, Söder, 2008, p. 217).

36 Albert the Great, De homine lib. II (ed. Anzulewicz, Söder, 2008, p. 216). 
inside it after the first imposition. ${ }^{37}$ Ps.-Kilwardby, who in his comments on Priscianus Maior (ca. 1250) repeatedly quotes Aristotle's De anima, ${ }^{38}$ addresses the same question about how to unify an intelligible species with a phonic matter, but he solves it by claiming that, in the moment of the first institution, a form (the meaning) is added to the vocal sound, analogous to the model of the "information" of the body by the soul. ${ }^{39}$ Such a form/matter model is consistent with the idea that words cannot lose their original meaning. ${ }^{40}$ The first imposition, indeed, remains (manet), ${ }^{41}$ according to its exemplar model, and the first act of imposition has the force of law. ${ }^{42}$

Finally, we can mention another question, which actually cannot be numbered with Albert the Great's questions on the De homine since it is not presented there, nor, as already mentioned, can it exhaust the questions about De anima II.8 discussed in the period, but it is related to questions (1) and (2) above. In question-commentaries on De anima II.8, medieval masters wondered about the specific difference of human language (loquela/locutio) $)^{43}$ (often formulated as "What is added to the vocal sound in

37 See Rosier, 1994, p. 125.

38 Ps.-Kilwardby, Commenti super Priscianum maiorem extracta, 2.1 (ed. Fredborg, Green-Petersen, Nielsen, Pinborg, 1975, pp. 57-64).

39 Ps.-Kilwardby, Commenti super Priscianum maiorem extracta, 2.1 (ed. Fredborg, Green-Petersen, Nielsen, Pinborg, 1975, p. 61). Cf. Cesalli, Majolino, 2014, §§ 91-124.

${ }^{40}$ For a discussion, see Rosier-Catach, 2020, p. 34.

41 Ps.-Kilwardby, Commenti super Priscianum maiorem extracta, 2.1 (ed. Fredborg, Green-Petersen, Nielsen, Pinborg, 1975, p. 63).

42 Ps.-Kilwardby, Commenti super Priscianum maiorem extracta, 2.1 (ed. Fredborg, Green-Petersen, Nielsen, Pinborg, 1975, p. 73). On Ps.-Kilwardby semantic, see Cesalli, Majolino, 2014, §§ 91-124; de Libera, 1981; Marmo, 1994, pp. 110-136; Marmo, 2010, pp. 71-79; Panaccio, 1999; Rosier-Catach, 1994, pp. 126-131.

43 There is a fluctuation in the Latin terminology to designate capacity of language (or speech capacity), and each word carries with it different nuances. Leaving aside idioma (which almost always means "idiom" or "a particular language"), sermo (found, for instance, in the medieval tradition of Aristotle's Politics) could be translated as "speech." However, only a lexicographical survey could try to understand the different medieval usage of locutio and loquela, which seems to be similar to designating the faculty/capacity of language. One hypothesis is that loquela might be related to the medieval tradition of Historia Animalium, and to biological and animal investigations (as the Latin equivalent of $\delta$ ió $\lambda \varepsilon \kappa \tau o v)$, while locutio seems to be used generally in the tradition and commentaries of De anima and Politics, as interchangeable with sermo. Regardless, I prefer to translate locutio/loquela as language, and sermo with speech, 
order to be language?"44). In fact, according to both Geoffrey of Aspall and Anonymous of Erfurt — a similar commentary dated around $1250^{45}$ —locutio is a species of the genus vox. ${ }^{46}$ Geoffrey of Aspall defines locutio as the utterance of a vocal sound that is significant by imposition in a certain language (prolacio vocis significantis ab impositione in alico certo ydiomate), and he states that it is the virtus rationalis that is added to the vocal sound. For this reason, animal language, which is generally (communiter) called loquela, cannot properly be labelled as such. Indeed, the rational faculty, proper to humans, is nobler than the imagination and appetitive faculty, and therefore "voces brutorum significant naturaliter et non ad placitum."

The same issue is addressed by Anonymous of Erfurt, who points out that the difference between vocal sound and language (locutio) is that the latter adds to the vocal sound "the imposition of a certain voluntary signification" (impositio significacionis spontanee certe). Imposition is fundamental to defining human language and how it differs from the vocal sound of animals (vox brutorum), that is, the species of vocal sound opposed

because of communicational and dialogical nuances implicit in the latter. See below, $\S 2$. On the complexity of such a lexicon, see Sekizawa, 2010, p. 70; Rosier-Catach, Cassin, Caussat, Grondeux, 2004; Von Moos, 2011.

${ }^{44}$ See, for example, Anonymous of Erfurt, Quaestiones in libros II e III de anima II (Erfurt, Universitatbibliotek, Dep. Erf., CA 4 312, f. 45 vB, quoted in Köhler, 2014, p. 417): "Queritur igitur, quid additum supra vocem vel vocacionem contrahit ipsam in locucionem tanquam in speciem." See also Geoffrey of Aspall, Quaestiones super librum de anima, II (ed. Čizmić, 2005, p. 323): "Unde adhuc remanet questio, quid additum voci constituit hanc speciem, que est locutio."

${ }^{45}$ See Raedemaeker, 1968-1970, pp. 195-203; Wood, 2018, p. 61.

${ }^{46}$ Geoffrey of Aspall, Quaestiones super librum de anima, II (ed. Čizmić, 2005, p. 323), Anonymous of Erfurt, Quaestiones in libros II e III de anima II, f. $45 \mathrm{vB}$ (quoted in Köhler, 2014, p. 417).

47 Geoffrey of Aspall, Quaestiones super librum de anima, II (ed. Čizmić, 2005, p. 324): "Dico quod locutio est species vocis. Est autem descripcio eius hec. Locutio est vocis significantis ab inpositione in alico certo ydiomate prolacio. Unde per illam particulam vocis significantis ab inpositione excluduntur vociferaciones brutorum, que secundum communiter loquentes dicuntur loquele extendendo nomen, inproprie tamen, quia ille voces secundum quod proferentur a brutis significant naturaliter, ut dicunt quidam et non ad placitum. [...] Unde prolacio vocis significantis ad placitum in ipso proprie non potest esse sine anima rationali. Unde virtus rationalis est illud superadditum appetitive cum ymaginatione in generatione locutionis." 
to loquela ${ }^{48}$ In fact, according to Anonymous of Erfurt, it is only equivocally said that birds speak, since they speak only according to simple use and habitude and not according to reason, like humans. ${ }^{49}$

The more general scenario, in which these questions concerning both the relationship between animal and human language and the nature of human language are framed, is certainly the distinction between ad placitum and natural signs. In arts faculties, the picture of the natural/ad placitum gap is generally inspired by the tradition of Peri Hermeneias (16 a19-29). Here, Boethius translates with secundum placitum the Aristotelian expression for which names, verbs, and sentences signify by an implicit agreement or

${ }^{48}$ Anonymous of Erfurt, Quaestiones in libros II e III de anima II, f. 46 rA (quoted in Köhler, 2014, p. 424): "Ad hoc dicendum, quod locucio est species vocacionis et quod locucio addit supra vocem, scilicet imposicionem significacionis spontanee certe. Unde sic debet diffiniri locucio: locucio est vox inposita ad significandum in alico certo idiomate, ut affectus unius alii significe $<\mathrm{n}>$ tur. Vox autem est generaliter sive significet naturaliter sive ab imposicione ut aliis significet, quod apud se est. Unde vox diffinita ab Aristotile potest dividi per vocem significativam naturaliter quod penes se est, et talis est vox brutorum, et ad placitum, et talis est locucio. Et ita patet, quid additum supra vocem contrahit ipsam in speciem, que est locucio, et eciam que est species opposita locucioni, cum genus non divid $<\mathrm{a}>$ tur per unicam speciem tantum."

${ }^{49}$ Anonymous of Erfurt, Quaestiones in libros II e III de anima II, f. 46 rA (quoted in Köhler, 2014, p. 424): "Ad illud, quod obicitur, quod aves loquntur, dicendum, quod equivoce loquntur aves et homines. Unde non dicitur proprie locucio, sed garritus, quia fit per (preter E) motum consuetum nature et a solo usu. Locucio autem humana non fit a solo usu, sed eciam ab usu et $\mathrm{r}<\mathrm{acion}>\mathrm{e}$ Patet eciam ultimo quesitum, an bruta loquntur, quia quod non $<$ videtur $>$ (v.] $\mathrm{n}<$ atur $>\mathrm{a}<$ lite $>\mathrm{r}$ cod.), tamen affectus proprie mentis ad se invicem exprimunt sub quadam specie vocis, ut prepatet. Nec habet nomen sibi proprium et bene posset vocari locucio brutorum, nec tamen locucio simpliciter." For a deeper analysis of this passage, I refer to Köhler, 2014, p. 424 and ff. and his bibliography on the relationship between human and animal language. The secondary literature is rich (see below); I want only to point out that other authors also claim that animal speech is ruled by usage and habit because of its naturalness. See Thomas Aquinas, Sententia libri politicorum, lib. I, cap. 1, 29 (ed. Leonina, 1971): "Videmus enim quod cum quaedam alia animalia habeant vocem, solus homo supra alia animalia habeat locutionem; nam etsi quaedam animalia locutionem humanam proferant, non tamen proprie loquntur, quia non intelligunt quid dicunt, sed ex usu quodam tales voces proferunt." 


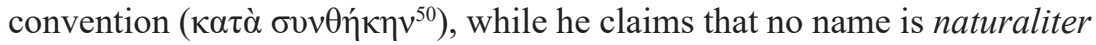
( $\varphi v \sigma \varepsilon 1)$ significant, as in the case of animal sounds, which are not literate. ${ }^{51}$ More generally, among late medieval thinkers, artists and theologians, the picture is complex, and both ad placitum and naturaliter are intended in multiple ways. ${ }^{52}$ Ad placitum is used according to different nuances of meaning, sometimes collective, as convention, sometimes individual, as voluntary or intentional, in the latter case often being influenced by Augustine's semiotic. ${ }^{53}$ In any case, the most appropriate translation remains "at pleasure" 54 . There are different ways of understanding even naturaliter. For example, the classifications of signs, such as those of Ps.-Kilwardby or Roger Bacon, consider among the natural signs the inferential or intentional signs as they are presented in Augustine's De doctrina christiana ${ }^{55}$ In most of the texts of the arts masters considered, however, the authors do not seem to elaborate the distinction between natural and ad placitum on Augustinian criteria: as already seen, the common feature is that they all ground the opposition between ad placitum and natural voices on Avicenna and Albert, according to whom the former are distinct and diversified, while the natural ones are indistinct and the same for all. Therefore, in light of this

${ }^{50}$ See Noriega-Olmos, 2012, pp. 141-170. In n. 255, Noriega-Olmos discusses the problematic concept of "implicit agreement" and claims it might be consistent with Aristotle's view.

${ }^{51}$ Aristoteles Latinus, De interpretatione (ed. Minio-Paluello, 1965, p. 6: 4-6; 16a 19-21): "Nomen ergo est vox significativa secundum placitum sine tempore [...]. 'Secundum placitum' vero, quoniam naturaliter nominum nihil est, sed quando fit nota; nam designant et inlitterati soni, ut ferarum, quorum nihil est nomen."

52 As Peter of Spain claims, according to medieval authors, natura dicitur multipliciter, cf. Petrus Hispanus, Quaestiones super libro “De animalibus”, lib. IV, q. 4 (ed. Navarro Sánchez, 2015, p. 187). For naturaliter in animal language, see Eco, Marmo, Lambertini, Tabarroni, 1989; Rosier-Catach, 2004, pp. 57-65.

${ }^{53}$ For the meaning of ad placitum and its bibliography, see Rosier-Catach, 2004, p. 63; Rosier-Catach, 2011, pp. 259-261, and below § 2 .

${ }^{54}$ See Ashworth, 2013, p. 259.

55 See, for instance, Ps.-Kilwardby, Commenti super Priscianum maiorem extracta, 1.1 .1 (ed. Fredborg, Green-Petersen, Nielsen, Pinborg, 1975, pp. 2-5) and Roger Bacon, De signis, $\S \S 1-15$ (ed. Fredborg, Nielsen, Pinborg, 1978, pp. 81-86). Augustine, De doctrina christiana, II.1, see Marmo, 2010, pp. 71-92; Cesalli, Rosier-Catach, 2018, and their bibliography. 
tradition, ${ }^{56}$ all of these authors re-elaborate the distinction presented in the Peri hermeneias. ${ }^{57}$

\section{A Pragmatic Theory of an Everyday Imposition of Words}

The text of Anonymous of Prague, a question-commentary preserved only in a composite and complex manuscript in the Metropolitan Library of Prague (MS 80, ff.42rA-89rA), dated around the $1250 \mathrm{~s}-60 \mathrm{~s}$, and probably written by an English arts master, ${ }^{58}$ can be contextualized within the textual tradition of question-commentaries on the De anima presented above. However, it is in relation to the theories of meaning of his contemporaries (already partially sketched in $\S 1$ ) that we can reach a better understanding of his originality.

Anonymous of Prague devotes approximately five questions of his commentary to language, qq. II.40-II.44, according to Ebbesen's list of questions. ${ }^{59}$ The first (q. II.40) investigates the definition of vox, asking what differentiates it from a simple sound ("What does the vocal sound add to the sound?"-quid addit vox supra sonum). The answer, which echoes Aristotle's De anima definition described above, gives the author the opportunity to explain which physiological characteristics determine the tone of voice. The degree of curvedness, thinness, and flexibility of a membrane inside the trachea (pellicula) determines a voice's acuteness or lowness, for both humans and animals such as oxen. Although it is not among the most debated topics in the De anima corpus of question-commentaries,

${ }^{56}$ I would like to thank Irène Rosier-Catach for having made me notice Avicenna as a common source. See n. 22.

57 See, for instance, Boethius' commentary on Peri hermeneias. Boethius, Commentarii in librum Aristotelis Peri hermeneias. In Peri hermeneias 1 (ed. Maiser, 1880, p. 47): "Huismodi ergo voces, quae secundum positionem sunt, secundum ponentium placitum sunt. Sed nomen non naturaliter significat. Apud diversas enim gentes, diversa sunt nomina. Quae autem apud diversa diversa sunt, ea non sunt naturaliter sed secundum placitum eorum qui posuerunt positionemque ponentium."

58 See below, $\S 3$.

${ }^{59}$ Ebbesen, 2020, p. 9. I present below the edition of qq. II.40-II.43; q. II.44 is has been edited by Ebbesen, 2020. 
Albert the Great focused on this subject in two questions of his De voce $e^{60}$ and addressed it in his De animalibus ${ }^{61}$ The latter must be one of the sources for these discussions since Anonymous of Prague also refers to his questions on De animalibus ${ }^{62}$ (II.40). However, the actual answer to question II.40 is presented in the subsequent short question II.41, where Anonymous of Prague states that a cough is different from a vocal sound because a vocal sound has received a form or, he says, an informatio, to express the conceived imagination. He writes:

Aristotle's expression is to be understood in this way, namely that the voice is accompanied by the imagination as far as it receives a form from those whose function is to do so, so that it is configured to express the conceived imagination. On the other hand, although a cough sometimes occurs with the imagination, however, that sound does not receive such a form and therefore does not deserve to be called voice. If one wonders what the voice adds to the sound, one must say the configuration (informatio) ${ }^{63}$

Early Modism or, as already seen, grammarians close to it such as Ps.-Kilwardby, adopt from Aristotle the form/matter model in order to explain the signification of words (ratio significandi). For that theory, the substantial form is the meaning added, as an intrinsic property, to the phonic matter and thanks to which a vocal sound became a word (dictio).$^{64}$ Here, however, Anonymous of Prague is not concerned with form as meaning. For this reason, I prefer to understand informatio as "configuration" rather than "form," "notion," or "representation," depending on how it is used in the authors who discuss the same issues. Anonymous of Vennebusch, for

${ }^{60}$ Albert the Great, De homine, qq. 3-4 (ed. Anzulewicz, Söder, 2008, pp. 218 220): De differentiis vocum quae sunt acutum et grave; De mutatione vocum secundum sexum et aetatem.

${ }^{61}$ See also Albert the Great, De animalibus, lib. IV, tract. 2, cap. 2, § 97 (ed. Stadler, 1916-1920, p. 401). See Perfetti, 2012, 2017.

${ }^{62}$ Indeed, the issue is inspired by Aristoteles, Historia Animalium, lib. IV, cap. 9 (536b5). See Rossi, 2017.

${ }^{63}$ Anonymous of Prague, Quaestiones de ente et anima, lib. II, q. II.41, p. 44: 11. 17-24. Unless otherwise specified, all translations are mine.

64 Marmo has defined it "Semiotica dell'organismo," see Marmo, 1994, pp. 109-136; and Cesalli and Majolino "poiesis-oriented approach," see Cesalli, Majolino, 2014, $\S \S 91-124$. 
instance, argues that vox is different from sound because it receives a shaping (figuratio) with respect to sound, that is, a configuration of the air (informatio aeris) determined by its passage through the trachea, through which voices are diversified from one another. ${ }^{65}$ This configuration, as far as the word is involved (figuratio dictionis), according to Albert the Great, must be distinguished from its meaning: he claims that it is the product of the phonatory organs of speech, directed by the soul, which produces configurations of sound to express its imagination. ${ }^{66}$ If my translation is consistent, Anonymous of Prague is simply saying that a voice is different from a simple sound because those things whose function is to do so (illi quorum officium est ad hoc deputatum), i.e., the phonatory organs, have given it a form, namely, a "phonic configuration," to express the imagination. ${ }^{67}$

${ }^{65}$ Anonymous of Vennebusch, Quaestiones in tres libros de anima, q. 47 (ed. Vennebusch, 1963, p. 220): “Ad primum istorum respondendum est, quod vox est una species essencialis soni, distincta contra sonum qui non est vox; et hoc propter diversam figuracionem quam recipit vox in sui generacione super sono alios, sicut in vocibus simplicibus litterarum una littera secundum speciem distinguitur ab alia propter diversam figuracionem et informacionem aeris in vocis generacione."

${ }^{66}$ Albert the Great, De anima, lib. II, cap. 22 (ed. Stroick, 2009, p. 131): "Forte autem dubitabit aliquis, cum duo sint in voce, scilicet figuratio dictionis et significatum, quid faciat in ipsa significatum. Et ad hoc aliquando aliqui dixerunt, quod conceptus, qui est ex parte intellectus, descendit in imaginationem, et organum illius est in anteriori parte capitis, ad quam pervenit respiratus aër, in quo vox figuratur, et ibi generat vis imaginativa intentionem rei in voce. Sed hoc absurdum esse videtur [...]. Oportet igitur, quod anima imaginans et intendens significare conceptum verberet aërem in arteria existentem ad ipsam arteriam; et in veritate pulso aëre ad arteriam, fit sonus, qui est materia vocis, sed figuratio ipsius soni in dictiones est per linguam et dentes et palatum et cetera interpretationis organa."

67 The expression "ab illis quorum officium est ad hoc deputatum" is ambiguous by virtue of the plural pronoun "ille, -a, -ud" which can indicate both people and souls as well as things, as I understood it referring to the phonatory organs. However, I excluded it as referring to people, who would be in this case the original language impositors, because the passage explains the configuration of the vox (and not the locutio), which is common to humans and animals. In this sense I also think it is highly implausible that it refers to animal individuals having a specific vocal configuration task, which would imply an animal social organization that I do not think is concerned here. Finally, I excluded it as referring to souls in analogy to Albert's passage where figuratio vocis is the prerogative of the phonatory organs. cf. supra n. 66. I thank Laurent Cesalli for suggesting to me that "illis" could refer to "something," besides "someone". 
The quaestio that follows (q. II.42) asks what language (loquela) adds to the vocal sound, or, in other terms, what differentiates human language from animal communication. Animals, in fact, communicate their imaginations with one another through their vocal expressions (vociferationes). ${ }^{68}$

The question concerns the nature of language and its difference from the vocal sounds of animals. If, according to De anima, vox is a vocal sound with a mental image, what differentiates humans' language from animals' expressions? If animals have imagination and utter voces with images, do they speak in the proper sense? The underlying source for Anonymous of Prague is, on the one hand, the beginning of Aristotle's Politics, where the philosopher argues that vocal sound is common to all animals, while speech (sermo) is proper only to humans, who can communicate moral values and build a community. ${ }^{69}$ On the other hand, the main source is De historia animalium, where Aristotle argues that language is proper to humans and that "not all those that have vocal sounds also have language."70 A few lines earlier, however, Aristotle said that birds have not only vocal sound but also language (loquela, in Moerbeke's translation ${ }^{71}$ ), especially those that have a large tongue. ${ }^{72}$

68 Anonymous of Prague, Quaestiones de ente et anima, lib. II, q. 42, p. 44: 11. 28-32.

69 Aristoteles Latinus, Politica, lib. I, cap. 2 (ed. Susemihl, 1872, p. 8; 1253a). On this topic, see Briguglia, Gentili, Rosier-Catach, 2020; Briguglia, 2015; Rosier-Catach, 2015. For the translation of sermo, see above n. 44.

${ }^{70}$ Aristoteles Latinus, De historia animalium. Translatio Guillelmi de Moerbeka, lib. 4, cap. 9 (ed. Beullens, Bossier, 2000, p. 123): “Animalifica autem et quadrupedia animalia aliud aliam vocem emittit, loquelam autem nullum habet, sed proprium hominis est; quecumque quidem enim loquelam habent, et vocem habent, quecumque autem vocem, non omnia loquelam habent. Quicumque autem fiunt surdi a nativitate, omnes muti fiunt; vocem quidem igitur emittunt, loquelam autem nullam."

${ }^{71}$ Aristoteles Latinus, De historia animalium, lib. 4, cap. 9 (ed. Beullens, Bossier, 2000, p. 122). Providing the translation from Greek to Latin by Moerbeke is only relevant up to a point. In fact, Historia Animalium (as one of the three parts of "medieval" De animalibus, which also contains De partibus animalium and De generatione animalium) entered the Latin world in the 1270s, and by that time many authors had commented on Michael Scot's translation from Arabic to Latin (1215), which is the most widely used (see Rossi, 2017). Unfortunately, Michael Scot's translation is only partially available: van Oppenraay recently published an edition of the first three volumes: see Aristoteles, De animalibus (ed. van Oppenraay 2020).

72 Aristoteles Latinus, De historia animalium. Translatio Guillelmi de Moerbeka, lib. 4, cap. 9 (ed. Beullens, Bossier, 2000, p. 122): “Avium autem genus emittit vocem, et 
To solve the puzzle, Anonymous of Prague argues that we can understand the ability to speak, or language (loquela), in three ways, from the least proper and most general to the most proper and correct. In the first sense, language is an animal's basic ability to communicate its mental images to another through the configuration of a vocal sound (formatio vocis ad imaginationem). In the proper sense, language is the articulated (litteralis) configuration of vocal sound for communication. ${ }^{73}$ According to Anonymous of Prague, this is an ability that trained birds have. They can learn images of human voices (imaginationes vocum humanarum), although they cannot grasp universal concepts. ${ }^{74}$ In general, Anonymous of Prague recognizes that animals have a form of semantic ability: animals can conceive the meaning of simple things, that is, sensible things. Thus, a dog understands its own name. This is, however, a "sensory" or "imaginative" knowledge because it knows the singular sensible thing but cannot know the universal in any way. ${ }^{75}$ However, birds can also articulate sounds: we can reasonably assume that litteralis (note that the author does not oppose another category to it) is synonymous with articulata, as intended in logical tradition, that is, both phonically articulated and writable. ${ }^{76}$

Finally, in the third sense, language consists of forming vocal sound articulated according to one's pleasure (secundum placitum) to signify images conceived by the soul. In this latter sense, language is the prerogative of human beings. ${ }^{77}$ As the author explains, the specificity of this third kind of language is, namely, the ad placitum language:

Accordingly, among all animals, human beings are said to speak in a very proper sense, since they utter articulated configurations of the vocal sound and institute them according to their pleasure with the aim of signifying; I do not mean according to the pleasure of the first impositor only, but according to the pleasure of any speaker whatsoever.

maxime habent loquelam quibuscumque existit mediocriter lingua lata, et quecumque ipsorum habent subtilem linguam."

73 See Anonymous of Prague, Quaestiones de ente et anima, lib. II, q. 42, p. 45: 11. 5-6.

${ }^{74}$ Anonymous of Prague, Quaestiones de ente et anima, lib. II, q. 42, pp. 45-46: 11. $31-13$.

75 Anonymous of Prague, Quaestiones de ente et anima, lib. II, q. 42, p. 46: 11. 10-13. For theories of animal intelligence in the Middle Ages, see Marmo, 2020; Oelze, 2018.

76 Eco, Lambertini, Marmo, Tabarroni, 1989, pp. 11-12; Rosier-Catach, 2003, p. 168.

77 Anonymous of Prague, Quaestiones de ente et anima, lib. II, q. 42, p. 45: 11. 6-10. 
For every human being is an impositor of all the names of his language (idioma). Therefore, those who impose in the same way, have the same language. Since the same concepts (species) are in everyone's soul, every day (cotidie) I impose the same vocal sounds to signify the same concept (species), those vocal sounds which I have heard more frequently being imposed by others (quas frequentius audivi alios imposuisse). Therefore, learning to speak is nothing else than learning the imposition of vocal sounds made by others and then imposing them in a similar way. ${ }^{78}$

In this account, any speaker, and not just the first impositor of language, establishes the configuration of vocal sounds, and especially institutes the meaning of words. As I have briefly explained, by "imposition" medieval scholars mean the act of giving names to things on the basis of which particular languages were instituted. The most common view is that human language originated from an act of imposition of meanings on the words performed "at pleasure" by an original name-giver (or nomothete). According to Genesis II.19-20, where God brought animals to Adam to see what he would call them, the impositor could be Adam himself; ${ }^{79}$ or, otherwise, he could be a metaphysician, who knows the properties of the words and can impose properly because of his knowledge, as Ps.-Kilwardby argues. ${ }^{80}$ Conversely, according to Anonymous of Prague, the will of the impositor involved in the act of naming and signifying is not the will of the first namegiver only. Imposing the meanings of words is an activity, which concerns every single common speaker of a particular language, and these meanings depend on their everyday use. No first name-giver can reclaim the authority to give a name to things, as Ps.-Kilwardby argues; on the contrary, every single human being is a name-giver.

78 Anonymous of Prague, Quaestiones de ente et anima, lib. II, q. 42, p. 45: 11. 9-17.

79 Dahan, 1995.

80 Ps.-Kilwardby, Commenti super Priscianum maiorem extracta, 2.1 (ed. Fredborg, Green-Petersen, Nielsen, Pinborg, 1975, p. 76): "Ad illud ergo quod querebatur, cuius sit voces instituere ad significandum, dicendum quod sapientis non cuiuscumque, sed principalis, qui habet auctoritatem super omnes alios sapientes, qui est philosophus primus; ille enim habet cognoscere res generaliter et earum generales proprietates et differentias, et propter hoc illius est voces ad significandum instituere et earum multiplicitatem distinguere." On this, see Ashworth, 2013; Cesalli, Majolino, 2014; Marmo, 1994, pp. 110-136; Rosier-Catach, 1994, pp. 126-131. It should be noticed that the expression ad placitum indicates that the act of imposition is voluntary and not necessarily arbitrary. Indeed, the names of things are often chosen with a reason; see Ashworth, 2013, p. 259. 
This idea is particularly important because there is a striking resemblance to what Roger Bacon says in his De signis when he introduces his theory of the imposition of words. In De signis Roger Bacon advocates a theory of the reimposition of words, according to which, if one wants, every human can impose the signification of words every day by giving them a new meaning. According to Bacon:

We act this way throughout the day (tota die) and renew the significates of words without the vocally expressed form of imposing, where a name is given to infants. ${ }^{81}$

Different from the imposition of names on infants, which are pronounced out loud during the baptism, the daily imposition can be tacit and not even conscious. ${ }^{82}$ As Cesalli has recently shown, two senses of imposition can be found in De signis. According to the first sense, imposition is naming things according to the will and reason of speakers. This imposition can be vocally expressed, and it institutes the words of particular languages. ${ }^{83}$ The other imposition, which is tacit and unconscious, is realized continuously and throughout the day (tota die), without almost being noticed. The first is usual and habitual, the second accidental. ${ }^{84}$ The process of daily imposition is that by which a word has a semantic transfer (transumptio). For example, as Goubier points out, ${ }^{85}$ according to Bacon, reimposition often happens beyond the will by the fact that a thing ceases to exist. Grounding his reflection on the rejection of the thesis of the univocal appellation of entities and non-entities, ${ }^{86}$ Bacon believes that if a thing ceases to exist, since a present thing and a past thing cannot be signified univocally but only equivocally, we - apparently unintentionally - reimpose the same word to signify a non-being. Goubier employs the example of the circulus

${ }^{81}$ Roger Bacon, De signis, $§ 155$ (ed. Fredborg, Nielsen, Pinborg, 1978, p. 130): “Et sic tota die facimus et renovamus significata dictionum sine forma imponendi vocaliter expressa, ut datur nomen infantibus" (Engl. trans. in Maloney, 2013, p. 107).

82 Roger Bacon, De signis, § 51 (ed. Fredborg, Nielsen, Pinborg, 1978, p. 100).

${ }^{83}$ See Roger Bacon, De signis, § 156-158 (ed. Fredborg, Nielsen, Pinborg, 1978, pp. 130-131).

${ }^{84}$ Cesalli, 2021, p. 191; Roger Bacon, De signis, § 157 (ed. Fredborg, Nielsen, Pinborg, 1978, p. 131).

${ }^{85}$ Goubier, forthcoming.

86 See de Libera, 1981. 
vini when the wine is over; and the name "Socrates" reimposed on "dead Socrates" during a commemoration seems to be a similar case. ${ }^{87}$ Moreover, in De signis, Bacon devotes several pages to develop meticulously very precise rules of equivocation, based on analogical inferences that usually guide speakers' reimpositions. ${ }^{88}$ However, it seems to me that Bacon does not limit the imposition as ad placitum nomination to the first origin of language. In $\S 157$, indeed, Bacon says that speakers can give names to the things they need to express. ${ }^{89}$ Free will (libertas), free choice (deliberatio), and pleasure (placitum) make this process of imposition available for every speaker. For this reason, and hence for the crucial role of the language's user, most scholars have talked about semantic freedom, as well as about a pragmatic or praxis-oriented approach to signification in such a medieval text. Cesalli and Majolino, for instance, have shown how, according to the medieval pragmatic approach, the meanings of words depend on their use by the actors of communication. Therefore, for Bacon too, signification is the result of an act of bestowing/conferring meaning that involves the speaker qua user of language and his/her intentions to signify. ${ }^{90}$ Although Bacon does not explicitly use the concept of intention to signify, he insists on the free nature of the signification, ${ }^{91}$ on the volitional intention as well as on the role of the will ${ }^{92}$ in both his classifications of the signs and his semantic account. The signs ad placitum, i.e., the signs of the human's language, are classified among the intentional signs, namely the signs instituted by

87 Roger Bacon, De signis, §§ 148-149 (ed. Fredborg, Nielsen, Pinborg, 1978, pp. 128-129).

88 See Cesalli, Rosier-Catach, 2018; Maloney, 1984; Marmo, 1997.

89 Roger Bacon, De signis, § 157 (ed. Fredborg, Nielsen, Pinborg, 1978, p. 131): "Si vero aliter fit impositio, hoc est propter alium finem quam propter linguam componendam, scilicet ut pro volutate cuiuslibet recipiat una res unum nomen vel plura secundum quod homo indiget uti re illa propter aliquas eius compositiones, conceptiones et imaginationes circa rem illam et tunc potest quilibet hoc facere, quia nomina sunt ad placitum."

90 Cesalli, Majolino, 2014, $§$ 125-167.

91 Roger Bacon, De signis, § 143 (ed. Fredborg, Nielsen, Pinborg, 1978, p. 34): "Scimus enim quod illud, quod est in libertate bene placiti nostri, non est necessarium. Sed significatio dictionum est huiusmodi, significant enim ad placitum, quare nihil est hic necessarium."

${ }^{92}$ Cesalli, Majolino, 2014, § 170. 
the soul — even of animals - in order to communicate something. ${ }^{93}$ Unlike animal signs, however, the signs "at pleasure" are instituted by reason and will. ${ }^{94}$ As is widely acknowledged, the classification of signs at the beginning of the De signis is strongly based on Augustine's De doctrina christiana. ${ }^{95}$ As Rosier-Catach has pointed out, however, although Bacon follows Augustine in emphasizing the importance of the will in establishing the value of signs, he does not take too much account of the consensual and collective dimension of the institution the latter suggests. ${ }^{96}$ Although the semantic freedom in Bacon is limited by some rules that regulate the new imposition, reimposition remains theoretically free ${ }^{97}$ and especially individual, without giving an explicit role to the community and to the speakers' mutual understanding. Indeed, we might say that Bacon's theory of imposition is a radicalization of what Engels saw as the most individual meaning of Boethius's secundum placitum. ${ }^{98}$

Probably, in understanding the danger for communication and the risks of Bacon's semantic freedom, Peter John Olivi argues that we cannot renew meanings as we wish to. By distinguishing actual signification, the act of bestowing meaning by speakers, and a habitual signification, the meaning established by an act of institution, ${ }^{99}$ Olivi gives a normative value to signification which speakers must respect. Indeed, each individual intention to signify and each act of "bestowing meaning," unless it is made explicit, must be based on common meaning shared by the community and

93 Bacon defines this kind of sign as datum ab anima; ordinatum ab anima or recipiens rationem signi ex intentione animae, see, Roger Bacon, De signis, §§ 7-8 (ed. Fredborg, Nielsen, Pinborg, 1978, pp. 83-84).

94 Roger Bacon, De signis, §§ 7-8 (ed. Fredborg, Nielsen, Pinborg, 1978, pp. 83-84).

95 See Rosier, 1994, pp. 95-112.

96 See Rosier, 1994, p. 137.

97 Roger Bacon, De signis, § 92 (ed. Fredborg, Nielsen, Pinborg, 1978, pp. 111-112): "Eadem enim ratio est quia quandocumque renovatur significatum erit aequivocatio et nomina sunt ad placitum nostrum et possumus transsumere nomina sicut volumus, <etiam si $>$ non ita utimur quibusdam aequivocationibus sicut aliis nec transsumimus nomina, et tamen possumus si volumus."

98 Engels, 1963.

99 Peter John Olivi, Quaestiones logicales. Critical text, q. 4 (ed. Brown, 1986, p. 5). 
established by an original agreement of people. As for Augustine and unlike Bacon's view, the collective dimension is at stake here. ${ }^{100}$

Therefore, as Goubier points out, if we ask ourselves whether in the Middle Ages we can find the pragmatic idea that "meaning is use" intended in a collective sense, i.e., in which mutual consent can be reached, we should not look for it in Bacon. ${ }^{101}$ However, this is not true for Olivi either, though for a different reason than Bacon's individual imposition: as Goubier says, in many medieval theories, linguistic meaning is not properly identical to use because we usually have a default signification of words that is more or less stable. ${ }^{102}$ All the other significations are variations of the stable ones. In fact, in the Middle Ages, the idea that the first imposition is an agreement of a community is more widespread than one might think. In addition to the texts indicated by Goubier, there are texts of thirteenth-century arts masters who deal with the Psammetichus experiment, ${ }^{103}$ whereby two children are left to grow up in isolation to find out which language they will speak spontaneously. Starting from this basis, arts masters often discuss the acquisition of language, or language innatism (also in De anima questioncommentaries as Anonymous of Prague does [II.44]). ${ }^{104}$ In commenting on the Psammetichus experiment, a text that is possible to attribute to Radulphus Brito says that language originates by communis consensus and through the agreement of one who gives his/her consent to another. ${ }^{105}$ Two anonymous authors in the same milieu claim that humans communicate and learn meanings of language by communication and use. ${ }^{106}$ In this case, it is

\footnotetext{
100 See Appolloni, 2020; Mora-Marquez, 2015; Rosier-Catach, 2004.

101 Goubier, forthcoming.

102 Goubier, forthcoming, 3.2.2.

103 See Ebbesen, 2017a, 2017b; Durand, 2017a, 2017b; Sekizawa, 2010.
}

104 Anonymous of Prague's answer is quite similar to that of other thinkers: he says that two children left in the desert without ever listening to human words would not speak a particular language, and therefore there is no such thing as an innate language.

$105<$ Raduphus Brito>, Quaestiones super librum De sensu et sensato, q. 8 (ed. Ebbesen, 2017, p. 161): "Minor patet, quia sermo est significativus ad placitum ex communi consensu plurium ad invicem consent $<$ ient $>$ ium; modo surdus a nativitate non potest communicare cum aliis in tali concordia et consensu; ideo non potest vocem significativam ad placitum alteri exprimere neque per consequens loqui, quia a quocumque removetur definitio loquelae et loquela."

${ }_{106}$ Anonymous Vaticani 3061, Quaestiones super librum De sensu et sensato, q. 8 (ed. Ebbesen, 2017, p. 168): "Maior patet, quoniam ille non habet loqui qui non habet 
a communitarian meaning of ad placitum, different from the individual ones classified by Engels. ${ }^{107}$ However, as Goubier points out, a communitarian origin of language, and the idea that there are always default meanings that we use, do not imply the idea that "meaning is use."

Is it the same for Anonymous of Prague? As Anonymous of Prague says, every day I usually impose names on mental images or concepts, but in doing so I follow the impositions that I have already heard from others and which are more commonly performed. The common use of meanings is the guide that any speaker should follow. Unlike Bacon's view, for Anonymous of Prague the community and the social agreement on meanings are fundamental, both for the use of the language and for its learning. In fact, learning and sharing a particular language is nothing more than listening to other people who impose names, and then doing the same. Nevertheless, unlike Bacon, this everyday imposition does not imply a deviation from the usual meanings.

Although we do not have the same freedom that we have in Bacon's account, semantic freedom is, for Anonymous of Prague, a fundamental peculiarity of human language:

From these considerations, it is clear what one must answer to the question of whether trained birds speak properly. Indeed, birds that utter vocal sound articulated (litterata) with the imagination lack the possession of language (loquela), because they do not have the ability to form different vocal sounds and to impose them according to their pleasure. Indeed, a well-trained bird cannot call things by any other word, as a human being can. For human beings can impose new vocal sounds for things throughout the day (tota die), over which there can be a mutual consent (mutuus consensus). Nevertheless, birds which are well-trained and form human vocal sounds associated to the same human mental images - that is, by having in their soul the images of the same

vocum distinctionem cognoscere, et etiam voces dearticulare, et hoc per usum quo communicat cum hominibus et utitur tali loquela cum hominibus; ideo $<$ non $>$ loquitur idioma determinatum ad placitum impositum;" Anonymous Vaticani 2170, Quaestiones super librum De sensu et sensato, q. 7 (ed. Ebbesen, 2017, p. 173): "Credo tamen istud non est verum secundum Philosophum, quia voces tales vel tales non sunt significativi huius aut illius nisi secundum placitum et voluntatem hominum, et ideo hebraicum idioma est ad placitum; modo de talibus quae sunt ad placitum nullus habet cognitionem nisi per communicationem et usum."

107 Engels, 1962, 1963. 
vocal sounds - are said to speak in the proper sense of the term, if compared to other animals besides human beings. However, with respect to human language they do not speak at all in the proper sense of the term. ${ }^{108}$

As we can see from this passage, rather than Bacon's mechanism of everyday language, the ability to signify in a different way is what characterizes the human species and the human language as opposed to the animal one. Birds and humans can share the same images of vocal sounds, but even if birds can articulate it, as parrots do, only human beings can "call things by any other word." Therefore, the creativity and the intrinsic freedom of human language mark the difference between it and the animal one. ${ }^{109}$ For this reason, Anonymous of Prague claims that, if someone wishes (or considers it appropriate), one can (potest) - has the freedom to-impose new vocal sounds on things throughout the day (tota die). ${ }^{110}$ Anonymous of Prague uses the same expression as Bacon's De signis, but he continues by stressing the importance of reaching a consensus on the new sound. ${ }^{111}$ This means sharing a language and thus ensuring mutual understanding.

108 Anonymous of Prague, Quaestiones de ente et anima, q. II, lib. 42, p. 45: 11. 18-29.

109 As Rosier-Catach has noted, Avicenna already underlines the creativity of human language, as opposed to that of animals, since humans can infinitely combine letters to form words according to the infinity of their desires. See n. 22 and its bibliography.

${ }^{110}$ It should be noticed that for Anonymous of Prague the new imposition consists in naming things with new names and not properly in a semantic renewal, as in the first sense of Bacon's imposition.

111 By emphasizing this aspect of mutual and common understanding, Anonymous of Prague seems closer to Olivi than to Bacon. Indeed, Olivi believes that under certain circumstances one can legitimately change the meanings of words. However, the conditions for making the change acceptable are quite traditional, especially the need for "some authority on the part of the impositor" (see Ashworth, 2013, p. 264; Peter John Olivi, In Mattheum 5:37 (ed. Corran, 2015, p. 111). Differently, according to Anonymous of Prague, there is no "aristocracy" or "noocracy" of naming and meaning. Instead, every speaker can do this freely even without any special knowledge or authority. 
Concluding Remarks about the Authorship: Adam of Whitby, Magister R. et alii

Multiple problems arise from the examination of manuscript 80, preserved in the Metropolitan Library of Prague, which contains the question-commentary presented above. According to Rega Wood's codicological description, ${ }^{112}$ it is a composite codex of six parts, apparently written in England in the thirteenth century, between approximately 1245 and 1275 . The codex contains several works from English authors, including Richard Rufus of Cornwall and Adam of Whitby, mostly commentaries on Aristotle, among which are two commentaries on De anima. However, the second part of the manuscript (80.2: ff. $42 \mathrm{rA}-89 \mathrm{rA}$ ), dated around 1250 by Wood, ${ }^{113}$ or, at the very latest, the 1260s by Ebbesen, ${ }^{114}$ contains Quaestiones de anima II and our questions. ${ }^{115}$ Moreover, it consists of four groups of questions, which Ebbesen designates using Greek letters: group $\alpha$ (69 questions on De anima II; approximately 7 on De Anima III); group $\beta$ (12 questions on De anima II; 5 on De Anima III); group $\gamma$ ( 2 questions on De anima $\mathrm{I}$ ); and group $\delta$ ( 17 questions on De anima I). ${ }^{116}$ The four sections of questions seem to be independent of one another; they are all anonymous except for some questions in the first group. Indeed, group $\alpha$ contains around eleven questions attributed (in a caption, with red ink on the margins) to Magister R. and approximately fifteen to Magister Adam Wyteby (or Magister Adam, or simply A.). The rest is anonymous. Hence, the corpus of questions of group $\alpha$ (but the same could be said for the others) is a collection of different sets of questions put together to create a more unified text by copying sections from each in turn. ${ }^{117}$ The ratio of such a composition seems to be to mix almost two sets of questions to exhaust a certain topic. For example, we can find questions about lux and color by Magister Adam (qq. 20-23), followed by a set of questions about lux and color attributed mostly to Magister R. (qq. 24-29: q. 26 and q. 28's attribution is unclear, and q. 27 is not attributed). The puzzle is further complicated by the fact that it

\footnotetext{
112 Wood, 2010.

113 Wood, 2010.

114 Ebbesen, 2020, p. 21.

115 Ebbesen, 2020, p. 9.

116 Ebbesen, 2020, pp. 2-20.

117 Ottman, Wood, Lewis, Martin, 2018, p. 62.
} 
is not clear whether the questions in group $\alpha-$ which include the questions edited below - are all by Magister R. or by Adam of Whytby. It is likely, however, that, for group $\alpha$, the writer had two sets of question-commentary, which he put together. In such a situation it seems incautious to attempt an attribution, which could be highly speculative and certainly beyond my reach.

For this reason, I will argue, though not in a definitive way, for a nonattribution to show how, in my opinion, these questions cannot be attributed to Bacon.

The hypothesis of an attribution to Bacon actually seems suggestive, and many arguments might be advanced in its favor. In fact, although the theory of everyday imposition is different from that of De signis (1267), there are few similar theories in the thirteenth-century milieu, and this formulation could be a sort of intermediate step in the development of his semantic theory of reimposition. Indeed, Bacon's question-commentary on De anima, which scholars place between approximately 1237 and $1245,{ }^{118}$ is lost, although nothing prevents us from post-dating it. The date of Bacon's stay in Oxford (ca. 1248-51) is still unclear to scholars but was at least before he entered the Franciscan Order in 1256/7. ${ }^{119}$

Such an attribution could explain some of the anomalies that Ebbesen found in his edition of the selected questions: Anonymous of Prague quotes and uses Augustine, which is a source for Bacon even before he became a theologian, and, above all, he shows an acquaintance with the Hebrew language. ${ }^{120}$ As Ebbesen points out, this is evident in question 44 on the Psammetichus experiment, which is closely related to qq. 40-43. Here, for instance, Anonymous probably relies on Augustine's Confessions when he deals with learning language by ostension. ${ }^{121}$ As for Hebrew, while

118 Delorme, 1935, p. XXX; Ottman, Wood, Lewis, Martin, 2018, p. 65.

119 Hackett, 1997, p. 15; Hackett, 2020.

120 Ebbesen, 2020, p. 22.

${ }^{121}$ Anonymous of Prague, Quaestio, II.44. (ed. Ebbesen, 2020, p. 27): "Verumtamen si essent cohabitantes in uno loco deserto, credo ipsos posse invenire unum novum idoma eis commune. Necessaria tamen esset eis sensibilis demonstration rerum inter eos, ut quando unus formet vocem ostendat alteri rem cui vult imponere, et quod illa vocis impositio memoriter retineatur penes utrumque vel alterum." See Augustine, Confessionum libri XIII, I.8 (ed. Verheijen, 1981). Actually, the same reference could be found in Ps-Kilwardby, see Cesalli, de Libera, Goubier, Rosier-Catach, forthcoming, § 147. 
arts masters wonder whether Hebrew is a natural language, ${ }^{122}$ Anonymous of Prague claims not only that speaking Hebrew is not a natural endowment but also that much learning and instruction (multa doctrina et instructione) is required for Jews. As Ebbesen pointed out, this suggests that "the author has some acquaintance with the situation among contemporary Jews," which is notable since the other authors seem to be unaware that Hebrew is only, at that time, acquired as a second language. ${ }^{123}$ Another remarkable sign of such an acquaintance with Hebrew is that he claims that producing words (formatio vocum) in Hebrew is easier than in any other language. ${ }^{124}$ For this reason, he argues, the words of isolated children may be more similar to Hebrew than to any other language. ${ }^{125}$ Ebbesen suggests that, "if the remark is not completely gratuitous, it suggests someone who has learned a bit of Hebrew himself and found it relatively easy." 126 Therefore, Roger Bacon seems to be a good candidate because, according to Hackett, "sometime after 1248, he set aside the common scholastic ways of teaching to devote time to languages and experimental concerns." ${ }^{127}$ Moreover, in his Opus tertium, ${ }^{128}$ when he wanted to resume its lost part of the De signis, Bacon shows that he dealt with the questions of innate language and acquisition. ${ }^{129}$ However, if we look at Bacon's corpus of mature works (1260s),

122 See Ebbesen's dossier of texts on Psammetichus' experiment (Ebbesen, 2017a).

123 See Dahan, 1990, pp. 229-289; Ebbesen, 2020, p. 22.

124 Ebbesen, 2020, p. 22.

125 Anonymous of Prague, Quaestio, II.44 (ed. Ebbesen, 2020, p. 27): "Nec credo hoc esse verum quod famose dicitur quod quilibet puer non instructus ad loquendum loqueretur hebraice. Illi enim qui modo loquuntur hebraice, ut iudaei, egent necessario multa doctrina et instructione. Item, apud hebraeos est ars loquendi recte et non recte; ars autem non est circa ea quae sunt a natura, nullus enim eget arte ad comedendum etc.; ergo loqui hebraice non est a natura. Verumtamen, quia facilior est vocum hebraicarum formatio - ut in pluribus, dico — quam formatio vocum aliorum idiomatum, ideo credo quod pueri in deserto magis convenirent in suis vocibus cum vocibus hebraicis quam aliis alterius idiomatis, non penitus et universaliter."

126 Ebbesen, 2020, pp. 22-23.

127 Hackett, 2020.

128 Roger Bacon, Opus Tertium, Opus Minus, Compendium Philosophiae (ed. Brewer, 1859 , p. 101).

129 After the resumé of De signis that was given to us, Bacon says that in his De Signis he deals with the double sense of Scripture, Sacraments, the first language of Adam and: "et an pueri in deserto nutriti aliqua lingua per se uterentur, et si obviarent sibi invicem 
in which he deals with Hebrew, there is no trace of a similar position on the configuration of vocal sounds. This is true for Opus tertium ${ }^{130}$ and Opus minus, ${ }^{131}$ but also for his Fragment of His Hebrew Grammar or the Notes on Hebrew attributed to him by Anheim, Grévin, and Morard, ${ }^{132}$ although the latter Notes devote several pages to comparative studies of languages and their phonic features. ${ }^{133}$

The attribution of our questions to Magister R. might be a very suggestive element to confirm the hypothesis of Roger Bacon. One could imagine that qq. 40-44, which seem to compose a unit, could be by Magister R., since they come after a part attributed to Magister R. himself (II.31) and before the attribution to Magister A. of q. 45. ${ }^{134}$ As Ebbesen has shown, some questions attributed to one of them are placed among the parts attributed to the other master. ${ }^{135}$ Moreover, even if the copyist could only have signaled a change of attribution, our part might still not be attributed to Magister R. because it could be by another author: nothing prevents group $\alpha$ from being composed of more than two authors. The first three questions (II.1, 2, 3),

quomodo mutuos indicarent affectus" (Roger Bacon, Opus tertium, p. 101). This indicates his acquaintance with this question, even though his commentary on De anima precedes his De signis. However, the questions are not exactly the same: Anonymous of Prague wonders whether a) natural language is innate to children educated in the desert without listening to language; and b) two children separated from each other will speak the same language, that is, if this natural language will be the same (Ebbesen, 2020, p. 26: "a) an ita insit homini naturalis loquela quod loqueretur quis etiam si ab infantia esset educatus in deserto neminem umquam audiendo; b) et si essent duo pueri [duo pueri] ab humana conversatione separati, etiam a se invicem, utrum, si ambo loquerentur, haberent eandem an diversam et diversam loquelam.") In a similar but more general way, Bacon wonders a) whether children nourished in the desert would use some language for themselves; and b) in which way they would communicate if they met.

130 Roger Bacon, Opus Tertium, Opus Minus, Compendium Philosophiae (ed. Brewer, 1859 , p. 65).

131 Roger Bacon, Opus Tertium, Opus Minus, Compendium Philosophiae (ed. Brewer, 1859 , p. 350).

132 Anheim, Grévin, Morard, 2001.

133 The text is preserved in the Municipal Library, Toulouse, Ms. 402, ff. 233ra43-278vb [T] and in the Laurentian Library, Florence, S. Croce, Pl. XXV sin. 4, ff. 182ra-213vb [F]. Correspondence (F, ff. 188 rA-207vA10) presents many of these examples.

134 Ebbesen, 2020, p. 9.

135 Ebbesen, 2020, p. 24. 
for instance, are not attributed. ${ }^{136}$ Moreover, even if one keeps supposing that Magister R. could be Bacon, one will be quite disappointed looking at the questions on color. In his commentary on De sensu et sensato (ca. 1240), Bacon argues that light (lux) and color (color) are species specialissime of what is visible (esse visibile) ${ }^{137}$ Magister $\mathrm{R}$, conversely, denies this explicitly. ${ }^{138}$

If one still believes that there is a way, or fertile ground, to attribute qq. 40-44 to Roger Bacon, I think that a doctrinal element is crucial. According to de Libera, ${ }^{139}$ Bacon's Summule dialectices could be dated to the beginning of the $1250 \mathrm{~s}$, which would make it a work contemporary to our questions. A brief doctrinal comparison between the two texts shows theories that are hardly compatible. In his Summule Bacon distinguishes three senses of vox: most commonly it can be taken as sound; less properly as the sound of animals, which can distinguish sounds and communicate with one another (including humans); and more properly as the voice of some animals, such as oxen, which do not distinguish sounds. ${ }^{140}$ This is a classification that has little to do with the De anima, which, indeed, is never mentioned. Hence, we might suppose that his question-commentary was written later. However, in the same section on De voce, Bacon admits that the intention of signifying (intentio significandi) $)^{141}$ is a criterion for distinguishing human/animal language, which Anonymous of Prague never mentions. Finally, in the Summule Bacon already assumes the thesis of the non-univocal signification to non-existing things. ${ }^{142}$ Of such a question, which is central to Bacon's semantics, there is no trace in qq. 40-43. Adding to this a brief lexical analysis that shows the differences between Bacon's

136 Ebbesen, 2020, p. 3.

137 Roger Bacon, Liber De Sensu et Sensato. Summa de Sophismatibus et Distinctionibus (ed. Steele, 1937, p. 48).

138 Magister R., Quaestiones de ente et anima, II.28, f. 51vA (working transcription by J. Ottman): "Unde lux et color non sunt in eodem genere logico; sunt tamen eiusdem essentiae, sicut principium et principiatum." See Raizman-Kedar, 2007. I would like to thank Monika Mansfeld for introducing me to this interesting aspect of Roger Bacon's thought and his theory of color.

139 Libera, 1986, p. 152.

${ }^{140}$ Roger Bacon, Summulae dialectices, I.2, $\S \S 10-13$ (ed. Libera, 1986, p. 226).

141 Roger Bacon, Summulae dialectices, I.2, § 23 (ed. Libera, 1986, p. 222).

142 Roger Bacon, Summulae dialectices, II.1 611 (ed. De Libera, 1986, p. 287). 
Summule and qq. 40-43, ${ }^{143}$ and the doctrinal divergences just examined, I consider such an attribution to be highly unlikely.

\section{Conclusion}

The nature of the composite manuscript and the great difficulty inherent in understanding its composition and authorship can only lead to partial and partially hypothetical conclusions. However, this does not prevent us from appreciating the interest in a theory of everyday imposition of meaning that has similar pragmatic accents to Bacon's, albeit less systematic than Bacon. Compared to Bacon's theory, the consensual aspect of continuous imposition is privileged, and meaning becomes an everyday act of the speaker that must intercept the most frequently heard common use. There is too little textual basis to say whether Goubier's question can be answered positively, namely whether in some medieval conception of signification "meaning is use." Certainly, in a sense it might be admitted, but the fact that we possess only a few questions does not give us a clue as to whether, for example, for Anonymous of Prague there is an established first and default meaning from which the others depart. However, the Anonymous mentions only once the first institutor of language and puts him on the same level of every other speaker who can institute signs at her/his pleasure like the name-giver does (non dico secundum placitum primi instituentis solum, sed secundum placitum cuiuslibet loquentis). In doing this, he suggests the idea that there is no hierarchy between the first institutor and the other speakers and, therefore, there is no "default" meaning with a privileged role.

This work, however, leads to another final remark: if the hypothesis of "non-attribution" is sufficiently convincing, then we can imagine that an everyday imposition of words is not only Bacon's original idea but circulates in different forms and environments. The occasion for discussion might in fact be the question of Albert the Great, in which imposition and use are questioned and which Rosier-Catach had already indicated as the debate in which inscribe Bacon's position. This is not to say that Augustine

143 I made a quick search for lemmas that seem to me characteristic of Anonymous of Prague, both in the Summule and the De signis, and I found: "cotidie" 0; "loquela" 0; "tota die" 4 [3 DS; $1 S L]$; "vocis formatio"1 [DS]; and "consensus" 0. 
is not influential, that his role is less crucial, or that there are not intersections between Augustinian linguistics and the philosophy of language of the early arts masters, as we have seen for Anonymous of Prague (although, of course, they are stronger in the theological milieu, as in the case with Bacon and Olivi). Rather, Anonymous of Prague's questions seem to point in the same direction as recent scholarly tendencies to attenuate the opposition between an Aristotelian tradition, which should be more interested in the formal aspects of linguistic meaning, and an Augustinian and theological one, which is more attentive to pragmatic approaches. ${ }^{144}$ If such considerations are consistent, perhaps the tradition of commentaries on Aristotle by arts masters might reveal further surprises.

144 See, for instance, Marmo, 1995; Mora-Marquez, 2015 and her Topica project: https://www.gu.se/en/research/topica-project. 
Anonymous Pragensis, Quaestiones de ente et anima, qq. 40-43 (ff. 54v-55r)

The text is preserved in a single composite manuscript: Prague, Metropolitan Chapter MS 80 (cited as P in note), descripted by Rega Wood at https:// rrp.stanford.edu/pragM80-xml.html. The following edition presents three questions, numbered 40 to 43 according to Sten Ebbesen's list of questions (Ebbesen, 2020).

As the copy is unique, it might be better to leave the orthography as faithful as possible to the text preserved by the manuscript. However, since the manuscript presents many morphological variations (placitum/placidum; displicentia/displacentia; sed/set; tertius/tercius; aliqua/alico; heesdem/ easdem etc.), it is very hard to follow consistently such a criterion. Accordingly, I preferred to normalize the text according to classical orthography. However, I did not use classical diphthongs to preserve the Medieval Latin orthography, since the manuscript is uniform and consistent under this respect. As for punctuation and paragraphs, they are my own and follow the argumentation of the questions. I offer conjectural solutions and report errors by indicating the version of the manuscript both in the footnotes and in the text with the signs described below. For Aristotle's texts I used the Bekker editions.

Such an edition has benefited from a partial transcription presented in Kölher (2014) and especially from the working transcription of the entire manuscript realized by Jennifer Ottman as part of the Richard Rufus of Cornwall Project coordinated by Wood and supported by the National Endowment for the Humanities. They kindly shared it with me, and I am extremely grateful to them. 
Sigla and Abbreviations

P codex Bibliothecae Metropolitanae Pragensis MS 80

// $55 \mathrm{rA} / /$ incipit columna sinistra folii 55 recto

i.m. dext. in margine dextra

i.m. sin. in margine sinistra

(?) de lectione vocis praecedentis dubitare licet

$<>\quad$ addendum censeo

[ ] delendum censeo

[[ ]] deletum habet codex

*** lacuna 


\section{Anonymous Pragensis \\ Quaestiones de ente et anima, qq. 40-43}

Quaestio II.40

54 vB Postea queritur de voce quid addit vox supra sonum.

Et hoc solvit Aristoteles quando vult quod vox sit sonus aeris respirati reverberati ad tracheam arteriam cum aliqua imaginatione.

Ergo trachea arteria instrumentum vocis dici potest sed tamen non est 10 vocis instrumentum secundum se totam sed secundum aliquid quod est in ea, ut pro pelliculam unam vel plures que extenduntur ex tran $<\mathrm{s}>$ verso intra tracheam arteriam, et tremit quando pellitur aer ad ipsam. Et quandoque tremit cum tanto impetu quod ille tremor efficit sonum audibilem, et ille sonus, cum fuerit emissus cum aliqua imaginatione, vox est. Quandoque autem tremit sed non cum tanto impetu ut ille tremor sit sonus, ut in simplici respiratione.

Et circa istam pelliculam faciunt ad vocis acuitatem hec tria, scilicet curvitas et tenuitas et magna tensio; et horum opposita faciunt ad vocis gravitatem sicut erat in sono circa cordam cithare. Curvitas autem illius pellicule provenit ex strictura trachee arterie et eius longitudo ex amplitudine et ideo pueri et mulieres acutiorem habent vocem quam viri. Tensio autem pellicule quedam est gratuita et tunc fit vox acutior, quedam naturalis causata a naturali complexione: complexionem enim siccam illius pellicule consequitur possibilitas ad magnam tensionem; humidam vero eius complexionem consequitur labilitas et impossibilitas ad rigidam tensionem. Eius aut $<\mathrm{em}>$ tenuitas vel spissitudo est ex eius naturali compositione. Placentia autem et displicentia in voce est ex planitia vel asperitate illius pellicule vel ceterorum meatuum per quos exit vox ita quod ex levitate causatur placentia, et ex asperitate displicentia.

Ex hiis subtiliter inspectis potest patere causa, ut credo, quia boves grossiorem et graviorem habent vocem in iuventute quam cum ad etatem pervenerint. Non potest vitulus in tantum tendere tracheam arteriam

9 Cf. Aristoteles, De anima II.8 (420b34) 18 acuitatem] acuciem P 19 magna] maxna P 29 planicia] planicie P $\mathbf{3 1}$ subtiliter] breviter P (corr. i. m. dext.) 33 arteriam] arteream $\mathrm{P}$ 
ut magis graciliter aer expiratur sicut potest cum factus fuerit bos; nec etiam habet tantam vim expulsivam nec attractivam aeris sicut bos et cum minori impetu feritur trachea ab aere, et liberalius exit aer a trachea vituli quam bovis. Unde quando bos nititur viriliter vocem emittere, et 5 cum omni impetu et vitulus similiter, vox bovis est acutior voce vituli. Sed, si non fiat visus emittendi vocem neque in bove neque in vitulo, vox bovis est gravior, ut patet in bubuctatione tauri sine violentia et tensione colli emissa; de hoc tamen planius tangetur in questionibus super librum De animalibus.

10

\section{Quaestio II.41}

55 rA Postea queritur super illud verbum quod est in diffinitione vocis scilicet quod vox sit cum imaginatione. Queritur vero si tussiens

15 proponat aliquid et intendat significare illud per tussim aut eius tussis debeat dici vox an non.

Dicendum quod non. Sed verbum Aristotelis sic est intelligendum scilicet ut vox sit ita cum imaginatione ut recipiat formam ab illis quorum officium est ad hoc deputatum ut informet $<$ ur $>$ ad expressionem concepte

20 imaginationis.

Tussis autem etsi quandoque fiat cum imaginatione, non tamen recipit ille sonus formam talem, et ideo demeretur tussis dici vox.

Unde si queratur quid addit vox supra sonum, dicendum informationem.

\section{Quaestio II.42}

Postea queritur quid addit loquela super vocem et an aliquo modo sit dicendum quod bruta loquuntur quando per suas vociferationes significant

30 aliis animalibus sue speciei suas imaginationes, ut gallina pullis et ovis agnis et gallus gallinis, et sic de ceteris animalibus completis.

1 graciliter] graeilieter $\mathrm{P} \mathbf{6}$ emictendi] emictandi $\mathrm{P} \mid$ bove] bone $\mathrm{P}$ 14 Cf. Aristoteles, De anima II.8 (420b34) 24 Copyist leaves six white lines 31 gallinis] galluis $P$ 
Ad hoc dicendum quod potest dici loquela communiter et proprie, et magis proprie sive omnino proprissime.

Communiter igitur dicendo loquelam potest dici quod omne animal loquitur alteri quando per talem vociferationem significat ei talem imaginationem. Propri<e $>$ autem dicitur loquela non quelibet vocis formatio ad imaginationem sed formatio litteralis. Magis sive maxime proprie dicitur loquela litteralis formatio vocis secundum placitum ad imaginationem significandam ab anima conceptam.

Homo igitur inter omnia animalia proprissime dicitur loqui, quia profert litterales vocis formationes, et eas instituit secundum sui placitum ad significandum; non dico secundum placitum primi instituentis solum, sed secundum placitum cuiuslibet loquentis. Quilibet enim homo impositor est nominum omnium sui idiomatis. Unde illi qui uno modo imponunt unum habent idioma. Cum eedem sint species in anima apud omnes, ego easdem voces eisdem speciebus significandis impono cotidie, quas frequentius audivi alios imposuisse. Unde discere loqui nihil aliud est quam discere impositionem vocum ab aliis factam et postea similiter imponere.

Ex hiis patet quid est respondendum ad hanc questionem, utrum aves instructe loquantur proprie. Aves enim proferentes voces litteratas cum imaginatione defficiunt a proprietate loquele, eo quod non habent potentiam diversas voces formandi et eas secundum placitum [[in]] imponendi. Non enim potest avis optime instructus alteris vocabulis quibuscumque res appellare, sicut potest homo. Tota die enim potest homo novas voces rebus imponere si haberet cum quo posset mutuum consensum habere; verumtamen aves bene instructe et formantes humanas voces cum eisdem imaginationibus humanis-idest habentes in animis earum vocum imaginationes - dicuntur loqui proprie respectu aliorum animalium preter hominem; respectu tamen loquele hominis nequaquam dicuntur loqui proprie.

Queritur tamen a quibusdam an hoc sit possibile scilicet quod aves easdem concipian[n]t // 55 rB // imaginationes vocum humanarum quas addiscunt, quas quid $<\mathrm{em}>$ imaginationes concipit homo per illas voces.

10 placitum] prolacidum $P \quad 13$ imponunt] add.i. m. sin. 24 mutuum] mutium $P$ 26 animis] animabus $P \quad \mathbf{3 2}$ addiscunt] addiscit $P$ 
Et dicendum quod bene est hoc possibile. Videmus enim quod etiam bruta concipiunt significationes vocum simplicium sicut patet ad sensum de cane qui cognoscit nomen quo solet appellari; et similiter concipiunt significationes vocum complexarum ut patet sepissime de equis

5 et bobus et canibus. Unde, si haberent potestatem formandi huiusmodi voces quas cognoscunt, loquerentur cum imaginatione. Et ita-firmiter estimo - faciunt aves instructe ad loquendum; aliter enim non narrarent ea que vident, nisi significatum vocis videndo conciperent suo modo et illud voce sibi instructa proferrent. Significatum enim complexi univer-

10 salis nullatenus potest aliquod brutum concipere in quantum universale. Non enim habet potestatem pertractandi aliquam significationem, et ideo tantum complexum singulare et sensibile potest concipere, sed non secundum quod valet ad cognoscendum universale: hoc enim solius rationis est.

Ex hoc patet quod canis currens ex tran $<$ s $>$ verso contra leporem non

15 habet hanc universalem cognitionem quod quelibet duo latera trianguli sunt longiora tertio, vel quod corda sit brevior arcu; sed habet cognitionem huius particularis quod hec duo latera sunt longiora tertio, vel quod hec corda sit brevior hoc arcu: cognitionem dico sensitivam sive imaginativam.

\section{Quaestio II.43}

Postea queritur an hoc sit ex parte corporalium instrumentorum an ex parte virtutum anime, quod quedam bruta, ut quedam aves, possunt

25 addi $<$ s $>$ cere loquelas et quedam animalia non.

Et dico quod non loquntur aves pre ceteris brutis $a<$ nima $>$ libus eo quod aliquam virtutem anime habent nobiliorem quam cetera animalia, sed quia habent virtutem appetitivam proximiorem sive promptiorem ad formandum voces $\mathrm{si}<\mathrm{mi}>$ les illis nostris quas audiunt, et[iam] etiam quia

30 habent instrumenta vocalia habiliora ad litteralem formationem faciendam quam habeant alia $a<$ nima $>$ lia.

Unde forte non est reputandum pro stultitia quod cum pulli capiuntur a nido qui sunt instruendi ad loquendum, quod linguis eorum apponatur

3 "Nota" i.m. dext. $\mathrm{P} \quad \mathbf{7}$ "Nota" i.m. dext. $\mathrm{P} \quad \mathbf{1 1}$ "Nota" i.m. dext. $\mathrm{P} \quad \mathbf{1 6}$ "Nota" i.m. dext. $\mathrm{P}$

29 nostris] nobis $\mathrm{P} \mid$ "Nota" i.m. dext. $\mathrm{P}$ 
sanguis lingue hominis. Multum enim habilitat sanguis ille forte subtilis lingue humane vocalia avis instrumenta ad aptius movendum in formando vocem.

Hiis autem duabus de causis quarum una sumitur ex parte anime et altera ex parte instrumentorum corporalium accidit similiter (?) quasdam 5 aves debiliores esse ad loquendum quibusdam aliis brutis et etiam quibusdam aliis avibus.

Quod autem non modica causa formandi vocem constet in instrumentis vocalibus patet. Duorum enim hominum easdem virtutes anime habentium, unus loquitur melius et alter peius, et hoc est propter meliorem $\quad 10$ et peiorem complexionem suorum vocalium instrumentorum. 


\section{Primary Sources}

Albert the Great (1890). Peri Hermeneias. In: A. Borgnet (ed.), Albertus Magnus Opera omnia, 2 vols. Paris: Vivès.

Albert the Great (1916-1920). De animalibus. Ed. H. Stadler. Münster: Aschendorff.

Albert the Great (1968). De anima. In: C. Stroick (ed.), Alberti Magni Opera Omnia. Vol. VII.1. Monasterii Westfalorum: Aschendorff.

Albert the Great (2008). De homine. In: H. Anzulewicz, J. R. Söder (ed.), Alberti Magni Opera Omnia. Vol. XXVII.2. Monasterii Westfalorum: Aschendorff.

Anonymous Bodley (1998). Sententia super II et III de anima. In: B.C. Bazan (ed.), Anonymi magistri artium (c. 1246-1247) Sententia super II et III de anima (Oxford, Bodleian Library, Lat. Misc. c. 70, f. 1ra-25b; Roma, Bibl. Naz. V. E. 828, f. $46 v b, 48 r a-52$ ra). Leuven: Peeters.

Anonymous Rome (1985). Lectura in librum de anima. In: R.A. Gauthier (ed.), Anonymi Magistri Artium (c. 1245-1250), Lectura in librum de anima a quodam discipulo reportata (ms. Roma Naz. V. E. 828). Grottaferrata (Romae): Ad Claras Aquas.

Anonymous Siena (2009). Quaestiones super librum de anima. In: P. Bernardini (ed.), Anonymi magistri artium Quaestiones super librum De anima (Siena, Biblioteca comunale, ms. L. 3.21, ff. 134ra-174va). Firenze: SISMEL.

Anonymous Pragensis (1998). Quaestiones super Aristotelis Sophisticos Elenchos. In: D. Murè (ed.), Anonymus Pragensis on Equivocation. Cahiers de l'Institut du Moyen Âge Grec et Latin, 68, 63-97.

Anonymous Vaticani (2017). Quaestione super librum De Sensu et Sensato. In: S. Ebbesen (ed.), Does Language Acquisition Depend on Hearing a Language? A Text Corpus. Cahiers de l'Institut du Moyen Age Grec et Latin, 86, 164-174.

Anonymous Vennebusch (1963). Quaestiones in tres libros de anima. In: J. Vennebusch (ed.), Ein anonymer Aristoteleskommentar des XIII. Jahrunderts. Paderborn: Verlag Ferdinand Schöningh.

Aristoteles (2020). De animalibus. In: A.M.I. van Oppenraay (ed.), Michael Scot's Arabic-Latin Translation, Vol. 1a: books I-III: History of Animals. Leiden: Brill.

Aristoteles Latinus, De anima. In: J. Decorte, J. Brams (ed.), Iacobus Veneticus translator Aristotelis. De anima, textus editionis quae paratur a $\dagger$ Decorte, ALD (A.L. XII.1). 
Aristoteles Latinus (1872). Politica. In: F. Susemihl (ed.), Aristotelis Politicorum libri octo cum vetusta translatione Guilelmi de Moerbeka). Leipzig: Tebner (A.L. XXIX.2).

Aristoteles Latinus (1965). De interpretatione. In: L. Minio-Paluello (ed.), De interpretatione vel Perihermeneias. Translatio Boethii. Bruges-Paris: Desclée de Brouwer (A.L. II.1-2).

Aristoteles Latinus (1984). Guillelmus de Moerbeka revisor translationis Aristotelis secundum Aquinatis librum. De anima. In: Fratrum praedicatorum (ed.), S. Thomae de Aquino Opera Omnia, T. XLV.1. Sentencia libri de anima. Roma: Commissio Leonina (A.L. XII.2).

Aristoteles Latinus (2000). De historia animalium. In: P. Beullens, F. Bossier (ed.), Translatio Guillelmi de Morbeka. Pars prima: lib. I-V. Leiden: Brill (A.L. XVII.2.1.1).

Augustine (1981). Confessionum libri XIII. Ed. L. Verheijen. Turnhout: Brepols (CCL 27).

Avicenna Latinus (1968). Liber de anima seu Sextus de Naturalibus. IV-V. Ed. S. Van Riet. Louvain-Leiden: Éditions Orientalistes-Brill.

Boethius (1880). Commentarii in librum Aristotelis Peri Hermeneias [In Peri Hermeneias 1; In Peri Hermeneias 2]. Ed. K. Meiser. Lipsiae: Teubner.

Geoffrey of Aspall (2005). Quaestiones super De anima. Ed. V. Čizmić. München: Unpublished.

Peter of Spain (2015). Questiones super libro "De animalibus" Aristotelis: Critical Edition with Introduction. Ed. F. Navarro Sánchez. Farnham-Surrey-Burlington, VT: Ashgate Press.

Peter John Olivi (1986). Quaestiones Logicales. In: S.F. Brown (ed.), Peter John Olivi "Quaestiones logicales". Critical Text. Traditio, 42, 335-388.

Peter John Olivi (2015). In Matthaeum 5:37. In: E. Corran (ed.), Peter John Olivi's Ethics of Lying and Equivocation: Casuistical Teaching Drawn from his Commentaries on Matthew 5:37 and Luke 24:28. Archivium Franciscanum Historicum, 108, 89-113.

Ps.-Kilwardby (1975). Commenti super Priscianum maiorem extracta. In: K.M. Fredborg, N.J. Green-Pedersen, L. Nielsen, J. Pinborg (ed.), The Commentary on "Priscianus Maior" Ascribed to Robert Kilwardby. Cahiers de l'Institut du Moyen Âge Grec et Latin, 15, 1-146. 
Richard Rufus of Cornwall (2018). Sententia cum questionibus in libros De anima Aristotelis. Ed. J.R. Ottman, R. Wood, N. Lewis, C.J. Martin. New York: Oxford University Press.

Roger Bacon (1859). Opus Tertium, Opus Minus, Compendium Philosophiae. Ed. J.S. Brewer, Opera quaedam hactenus inedita. Vol. I. London: Longman.

Roger Bacon (1902). The Greek Grammar of Roger Bacon, and a Fragment of his Hebrew Grammar. Ed. B.A. Edmond Nolan, S.A. Hirsch. Cambridge: Cambridge University Press.

Roger Bacon (1935). Questiones super libros octo Physicorum. Ed. F. Delorme, R. Steele. Oxford: Oxford University Press.

Roger Bacon (1937). Liber De Sensu et Sensato. Summa de Sophismatibus et Distinctionibus. ed. R. Steele. Oxford: Oxford University Press.

Roger Bacon (1965). Opus tertium, Opus minus, Compendium studii philosophiae, Epistola de secretis operibus Artis et Naturae, et de nullitate Magiae. In: J.S. Brewer (ed.), Opera quaedam hactenus inedita. London: Longman [1859] (reprint 1965, Nendeln, Lichtenstein: Kraus).

Roger Bacon (1978). De signis. In: K.M. Fredborg, L. Nielsen, J. Pinborg (ed.), An Unedited Part of Roger Bacon's "Opus Maius": "De Signis". Traditio, $34,75-136$.

Roger Bacon (1986). Summulae dialectices I-II. In: A. de Libera (ed.), Les Summulae dialectices de Roger Bacon. I. De Termino. II. De Enuntiatione. Archives d'histoire doctrinale et littéraire du Moyen Âge, 53, 139-289.

Thomas Aquinas (1971). Sententia libri politicorum. In: Commisio Leonina (ed.), Opera omnia. T. XLVIII (pp. 67-295). Roma: Editori di San Tommaso.

\section{Secondary Sources}

Anheim, É., Grévin, B., Morard, M. (2001). Exégèse judéo-chrétienne, magie et linguistique: un recueil de "notes" inédites attribuées à Roger Bacon. Archives d'histoire doctrinale et littéraire du Moyen Âge, 68, 95-154.

Anzulewicz, H., Söder, J.R. (2008). Prolegomena. In: H. Anzulewicz, J.R. Söder (ed.), Alberti Magni De homine (pp. v-xvii). Monasterii Westfalorum: Aschendorff.

Appolloni, C. (2020). Approccio pragmatico e libertà semantica: un confronto tra Ruggero Bacone e Pietro di Giovanni Olivi sulla teoria del significato. Documenti e Studi per la Tradizione Filosofica Medievale, 31, 311-332. 
Ashworth, J. (2013). Aquinas, Scotus and Others on Naming, Knowing, and the Origin of Language. In: J.L. Fink, H. Hansen, A.M. Mora-Marquez (eds.), Logic and Language in the Middle Ages: A Volume in Honour of Sten Ebbesen (pp. 257-272). Leiden: Brill.

Bazan, B.C. (2002). 13th Century Commentaries on "De anima": From Peter of Spain to Thomas Aquinas. In: G. Fioravanti, C. Leonardi, S. Perfetti (eds.), Il Commento filosofico nell'Occidente latino (secoli XIII-XV) (pp. 119-184). Turnhout: Brepols.

Bernardini, P. (2009). Introduzione. In: P. Bernardini (ed.), Anonymi magistri artium Quaestiones super librum De anima (pp. I-CI). Firenze: SISMEL.

Briguglia, G. (2015). L'animale politico. Agostino, Aristotele e altri mostri medievali. Roma: Salerno Editrice.

Briguglia, G., Gentili, S., Rosier-Catach, I. (2020). Introduction. L'homme comme animal politique et parlant. Philosophical Readings, 12 (1), 1-12.

Cesalli, L., Rosier-Catach, I. (2018). “Signum est in praedicamento relationis”. Roger Bacon's Semantics Revisited in the Light of His Relational Theory of the Sign. Oxford Studies in Medieval Philosophy, 6, 62-99.

Cesalli, L., de Libera, A., Goubier, F., Rosier-Catach, I. (forthcoming). Roger Bacon. De signis. Traduction et commentaire.

Cesalli, L., Majolino C. (2014). Making Sense. On the Cluster significatio-intentio in Medieval and "Austrian" Philosophies. Methodos, 14. Retrieved from: https://journals.openedition.org/methodos/4068?lang=en.

Cesalli, L. (2021). Roger Bacon et le problème de l' "impositio aequivoca". In: L. Cesalli, F. Goubier, A. Grondeux, A. Robert, L. Valente (eds). Ad placitum. Pour Irène Rosier-Catach (pp. 185-192). Roma: Aracne.

Dahan, G. (1990). Les intellectuels chrétiens et les juifs au Moyen Âge. Paris: Cerf.

Dahan, G. (1995). Nommer les êtres: Exégèse et théorie du langage dans les commentaires médiévaux de Genèse 2, 19-20. In: S. Ebbesen (ed.), Sprachtheorien in Spätantike und Mittelalter (pp. 55-74). Tübingen: Narr.

Delorme, F., Steele, R. (1935). Introduction. In: F. Delorme, R. Steele (ed.), Roger Bacon, Questiones super libros octo Physicorum. Oxford: Oxford University Press.

Durand, B. (2017a). Fictions d'isolement enfantin: Anthologie d'une expérience de pensée. Paris: Hermann. 
Durand, B. (2017b). Sauvages expérimentaux. Une histoire des fictions d'isolement enfantin. Paris: Hermann.

Ebbesen, S. (2017a). Does Language Acquisition Depend on Hearing a Language? A Text Corpus. Cahiers de l'Institut du Moyen Âge Grec et Latin, 86, 138-215.

Ebbesen, S. (2017b). Psammetichus's Experiment and the Scholastics: Is Language Innate? In: J. Pelletier, R. Moques (eds.), The Language of Thought in Late Medieval Philosophy: Essays in honour of Claude Panaccio (pp. 287-302). Springer.

Ebbesen, S. (2020). An Anthology of Questions on "De anima" in ms Praha, MK M.80. An Analysis with an Edition of Selected Questions. Cahiers de l'Institut du Moyen Âge Grec et Latin, 89, 1-44.

Eco, U., Lambertini, R., Marmo, C., Tabarroni, A. (1984). On Animal Language in the Medieval Classification of Signs. Versus. Quaderni di Studi Semiotici, 38/39, 3-38.

Edmond Nolan, B.A., Hirsch, S.A. (1902). Introduction. In: B.A. Edmond Nolan, S.A. Hirsch (eds.), The Greek Grammar of Roger Bacon, and a Fragment of his Hebrew Grammar. Edited from the MSS. with introduction and notes by the Rev. Edmond Nolan, B.A., and Hirsch, S.A. (pp. I-LXXV). Cambridge: Cambridge University Press.

Engels, J. (1963). Origine, sens et survie du terme boécien "secundum placitum". Vivarium, 1, 87-114.

Gauthier, R.A. (1984). La "Sentencia super librum de anima" d'Adam de Bocfeld. In: R.A. Gauthier (ed.), Sanctus Thomas de Aquino Opera omnia iussu Leonis XIII P.M. edita. Cura et studio Fratrum Praedicatorum XLV 1 Sententia libri de anima. Roma-Paris.

Goubier, F. (forthcoming). Signification et usage dans la philosophie médiévale du langage. In: B. Godart-Wendling (ed.), Usages de l'usage. Londres: ISTE.

Hackett, J. (1997). Roger Bacon: His Life, Career and Works. In: J. Hackett (ed.), Roger Bacon and the Sciences: Commemorative Essays (pp. 9-24). Leiden: Brill.

Hackett, J. (2020). Roger Bacon. In: The Stanford Encyclopedia of Philosophy. Retrieved from: https://plato.stanford.edu/archives/sum2020/entries/rogerbacon (16.01.2021).

Huang, Y. (2017). Introduction: What is Pragmatics? In: Y. Huang (ed.), The Oxford Handbook of Pragmatics (pp. 1-18). Oxford: Oxford University Press. 
Köhler, T.W. (2014). Homo animal nobilissimus. Konturen des spezifisch Menschlichen in der naturphilosophischen Aristoteleskommentierung des dreizehnten Jahrhunderts. T. 2. Leiden: Brill.

Libera, A, de (1981). Roger Bacon et le problème de 1' "appellatio univoca". In: H. Braakhuis, C. H. Kneepkens, L. Rijk (eds.), English Logic and Semantics: From the End of the Twelfth Century to the Time of Ockham and Burleigh (pp. 193-234). Nijmegen: Ingenium Publishers.

Libera, A., de (1986). Les "Summulae dialectices" de Roger Bacon. In: A. de Libera (ed.), Les “Summulae dialectices” de Roger Bacon. I. De Termino. II. De Enuntiatione. Archives d'histoire doctrinale et littéraire du Moyen Âge, 53, 139-170.

Magee, J. (1989). Boethius on Signification and Mind. Leiden: Brill.

Maloney, T.S. (1984). Roger Bacon on Equivocation. Vivarium, 22, 85-112.

Maloney, T.S. (2013). Roger Bacon. On Signs. (Opus maius, Part 3, Chapter 2). Translated with an Introduction and /notes by Thomas S. Maloney. Toronto: Pontifical Institute of Medieval Studies.

Marmo, C., Rosier-Catach, I. (2011). Introduction. Vivarium, 49 (1), 1-8.

Marmo, C. (1994). Semiotica e linguaggio nella scolastica: Parigi, Bologna, Erfurt 1270-1330. La semiotica dei Modisti. Roma: Istituto Storico Italiano per il Medio Evo.

Marmo, C. (1995). A Pragmatic Approach to Language in Modism. In: S. Ebbesen (ed.) Sprachtheorien in Spätantike und Mittelalter (pp. 169-183). Tübingen: Gunter Narr Verlag.

Marmo, C. (1997). Bacon, Aristotle (and All the Others) on Natural Inferential Signs. Vivarium, 35 (2), 136-154.

Marmo, C. (2010). La semiotica del XIII secolo: tra arti liberali e teologia. Milano: Bompiani.

Marmo, C. (2020). Per uno studio sull'intelligenza animale nella Scolastica medievale: facoltà estimativa, inferenze e segni tra XIII e XIV secolo. In: S. Gensini (ed.), La voce e il logos. Filosofie dell'animalità nella storia delle idee (pp. 79-110). Pisa: Edizioni ETS.

Mora-Márquez, A.M. (2011). Pragmatics in Peter John Olivi's Account of Signification of Common Names. Vivarium, 49, 150-164.

Mora-Márquez, A. M. (2015). The Thirteenth-Century Notion of Signification: The Discussion and Their Origin and Development. Leiden: Brill. 
Noriega-Olmos, S. (2012). Aristotle's Psychology of Signification. Berlin-Boston: De Gruyter.

Oelze, A. (2018). Animal Rationality: Later Medieval Theories 1250-1350. Leiden: Brill.

Ottman, J.R., Wood, R., Lewis, N., Martin, C.J. (2018). Introduction. In: J.R. Ottman, R. Wood, N. Lewis, C.J. Martin (ed.), Richard Rufus of Cornwall. Sententia cum questionibus in libros De anima Aristotelis (pp. 1-194). New York: Oxford University Press.

Panaccio, C. (1999). Grammar and Mental Language in the Pseudo-Kilwardby. Historisk-filosofiske meddelelser. Det Kongelige Danske Videnskabernes Selskab, 77, 397-413.

Perfetti, S. (2012). Animali pensati nella filosofia tra medioevo e prima età moderna. Pisa: Edizioni ETS.

Perfetti, S. (2017). La disseminazione del sapere sugli animali (dalla tarda antichità al XIII secolo) e l'iperaristotelismo di Alberto Magno. In: M.M. Sassi (ed.), La zoologia di Aristotele e la sua ricezione, dall'età ellenistica e romana alle culture medioevali (pp. 269-297). Pisa: Pisa University Press.

Raedemaeker, J., de (1966-1967). Informations concernant quelques commentaires du "De anima." Bulletin de Philosophie Médiévale, 8-9, 87-110.

Raizman-Kedar, Y. (2007). Questioning Aristotle: Roger Bacon on the True Essence of Color. The Journal of Medieval Latin, 17, 373-383.

Rosier, I. (1994). La parole comme acte: sur la grammaire et la sémantique au XIIIe siècle. Paris: Vrin.

Rosier-Catach, I. (2000). Aristotle and Augustine. Two models of Occidental Medieval Semantics. In: G.H. Singh, G. Manetti (eds.). Signs and Signification. Vol. 2 (pp. 41-62). New Delhi: Bahri.

Rosier-Catach, I. (2003). Variations médiévales sur l'opposition entre signification "ad placitum" et signification naturelle. In: H. Braakhuis, C.H. Kneepkens (eds.), Aristotle's Peri hermeneias in the Latin Middle Ages. Essays on the Commentary Tradition (pp. 165-205). Turnhout: Brepols.

Rosier-Catach, I. (2004). La parole efficace. Signe, rituel, sacré. Paris: Editions du Seuil.

Rosier-Catach, I. (2006). "Solo all'uomo fu dato di parlare." Dante, gli angeli, gli animali. Rivista di filosofia Neo-scolastica, 98, 435-466. 
Rosier-Catach, I. (2011). Glossario. In: A. Grondeux, R. Imbach, I. Rosier-Catach, Dante Alighieri. De l'éloquence en vulgaire. Traduction et commentaire sous la direction d'Irène Rosier-Catach (pp. 259-326). Paris: Fayard.

Rosier-Catach, I. (2015). Communauté politique et communauté linguistique. In: J.P. Genet (ed.), La légitimité implicite (pp. 225-243). Paris-Rome: Publications de la Sorbonne / Ecole française de Rome.

Rosier-Catach, I. (2020). "Multa vocabula ceciderunt ab usu." Les mots, le cercle de vin, et le beneplacitum du locuteur. In: P. Borsa, P. Falzone, L. Fiorentini, S. Gentili, L. Marcozzi, S. Stroppa, N. Tonelli (eds.), Per Enrico Fenzi. Saggi di allievi e amici per i suoi ottant'anni (pp. 25-41). Firenze: Le Lettere.

Rosier-Catach I., Cassin B., Caussat P., Grondeux A. (2004). Langue / Langage / Parole. In: B. Cassin (ed.). Vocabulaire européen des Philosophies. Dictionnaire des intraduisibles (pp. 675-684). Paris: Éditions du Seuil / Dictionnaires Le Robert.

Rossi, P.B. (2017). L'entrata dei libri "De animalibus" nel Medioevo latino. In: M.M. Sassi (ed.), La zoologia di Aristotele e la sua ricezione, dall'età ellenistica e romana alle culture medioevali (pp. 237-268). Pisa: Pisa University Press.

Sekizawa, I. (2010). Le naturalisme linguistique de Boèce de Dacie. Thèse de doctorat. Paris: Université Paris VII - Denis Diderot. Unpublished.

Valente, L. (forthcoming). "In divinis intellectualiter versari oportebit:" la critica dell'uso dell'immaginazione in teologia fra Severino Boezio e il XII secolo.

Van Oppenraay, A.M.I. (2020). Introduction. In: A.M.I. van Oppenraay (ed.), Aristoteles, De animalibus. Michael Scot's Arabic-Latin Translation. Vol. 1a: Books I-III: History of Animals. Leiden: Brill.

Vecchio, S. (1994). Le parole come segni. Introduzione alla linguistica agostiniana. Palermo: Novecento.

Von Moos, P. (2011) Sermo. Das Begriffsgeschischtliche auf und ab der Primärbedeutung "Gespräch.” In: I. Atucha, D. Calma, C. König-Pralong, I. Zavattero (eds.), Mots médiévaux offerts à Ruedi Imbach (pp. 669-679). Porto: Fédération Internationale des Instituts d'Études Médiévales.

Weijers, O. (2002). La structure des commentaires philosophiques à la Faculté des arts: quelques observations. In: G. Fioravanti, C. Leonardi, S. Perfetti (eds.), Il Commento filosofico nell'Occidente latino (secoli XIII-XV) (pp. 17-42). Turnhout: Brepols. 
Wood, R. (2010). Ms Description M80. Record prepared by Rega Wood. Retrieved from: http://rrp.stanford.edu/pragM80-xml.html (16.01.2020).

\begin{abstract}
The aim of this paper is to offer an edition of three anonymous questions on De anima II.8, contained in MS Prague, Metropolitan Chapter, M. 80, ff. 54vA$55 \mathrm{vB}$ and dated $1250-1260$. The text offers an original theory of the everyday imposition of words. To present it, I (i) analyze the contemporary question-commentaries on De anima II.8; (ii) I present the theory of everyday imposition by discussing the analogies with, and differences from, Bacon's contemporary pragmatic theory; and (iii) I discuss the hypothesis of the attribution of the text to Roger Bacon.
\end{abstract}

